OPEN ACCESS

Edited by:

Fatima Saleh,

Beirut Arab University, Lebanon

Reviewed by: Hussein H. Khachfe,

American University of

Beirut, Lebanon

Mohamad Y. Fares,

University of Glasgow,

United Kingdom

*Correspondence:

Zongping Wang

wangzp@zjcc.org.cn

Lingbin Du

dulb@zjcc.org.cn

tThese authors have contributed equally to this work and share first authorship

Specialty section:

This article was submitted to

Public Health Policy,

a section of the journal

Frontiers in Public Health

Received: 08 November 2021

Accepted: 19 January 2022

Published: 16 February 2022

Citation:

Wang L, Lu B, He M, Wang Y, Wang Z and Du L (2022) Prostate Cancer Incidence and Mortality: Global Status and Temporal Trends in 89 Countries From 2000 to 2019.

Front. Public Health 10:811044. doi: 10.3389/fpubh.2022.811044

\section{Prostate Cancer Incidence and Mortality: Global Status and Temporal Trends in 89 Countries From 2000 to 2019}

\author{
Le Wang ${ }^{1+}$, Bin $\mathrm{Lu}^{2 \dagger}$, Mengjie He ${ }^{3 \dagger}$, Youqing Wang ${ }^{1}$, Zongping Wang ${ }^{4 *}$ and Lingbin Du ${ }^{1 *}$ \\ ${ }^{1}$ Department of Cancer Prevention, Cancer Hospital of the University of Chinese Academy of Sciences (Zhejiang Cancer \\ Hospital), Hangzhou, China, ${ }^{2}$ Office of Cancer Screening, National Cancer Center/National Clinical Research Center for \\ Cancer/Cancer Hospital, Chinese Academy of Medical Sciences and Peking Union Medical College, Beijing, China, \\ ${ }^{3}$ Department of Nutrition and Food Safety, Zhejiang Provincial Center for Disease Control and Prevention, Hangzhou, China, \\ ${ }^{4}$ Department of Urology, Cancer Hospital of the University of Chinese Academy of Sciences (Zhejiang Cancer Hospital), \\ Hangzhou, China
}

Aims: To evaluate current status of prostate cancer incidence and mortality worldwide, and compare the global trends of incidence and mortality in the past two decades and in the most recent period.

Methods: Data on the incidence and mortality of prostate cancer for 174 countries in 2020 were obtained from the GLOBOCAN 2020 database, and associations with the human development index ( $\mathrm{HDI}$ ) were evaluated. Data for trend analyses in 89 countries from 2000 to 2019 were retrieved from the Global Burden of Disease 2019 platform. Age standardized incidence rate (ASIR) and mortality rate (ASMR) were calculated by using the Segi's population. The average annual percent changes (AAPC) of ASIRs and ASMRs were evaluated by joinpoint regression analysis.

Results: A total of 1414259 new cases of prostate cancer and 375304 related deaths were reported in 2020 globally. HDI was positively correlated with ASIRs $(P<0.001)$ and negatively correlated with ASMRs $(P<0.001)$. In the past two decades, ASIRs have been increasing in 65 countries, stable in 15 countries and decreasing in 9 countries, and ASMRs have been increasing in 19 countries, stable in 25 countries and decreasing in 45 countries, respectively. In the most recent period, 44 countries have increasing ASIRs, and 32 countries have decreasing ASMRs, respectively. For instance, in the United States of America, the AAPC of ASIRs significantly decreased by $0.62 \%$ and ASMRs significantly decreased by $1.22 \%$ from 2000 to 2019 , while the AAPC from 2015 to 2019 significantly increased by $0.49 \%$ for ASIRs and significantly increased by $0.48 \%$ for ASMRs.

Conclusion: The magnitude of increasing incidence and decreasing mortality of prostate cancer is attenuated in the recent period. Further study is needed to analyze the absolute effect of risk factors, PSA screening and treatment.

Keywords: prostate cancer, incidence, mortality, screening, prevention 


\section{BACKGROUND}

Prostate cancer is the second most commonly diagnosed cancer and the fifth leading cause of cancer death among men worldwide, with an estimated 1,414,000 new cancer cases and 375,304 deaths in 2020. Prostate cancer is the most frequently diagnosed cancer in 112 countries, and the leading cause of cancer death in 48 countries (1). It is worth noting that the burden of prostate cancer is supposed to increase owing to the population aging and economic growth (2).

Advancing age, black race, and family history are wellestablished risk factors for prostate cancer (3). Meanwhile, more lifestyle and dietary risk factors that might increase the risk of prostate cancer have been consecutively put forward, like obesity (4), fitness (5), diabetes mellitus (6), dietary patterns (7), and supplementation with vitamin E (8). Moreover, human development index (HDI), a summary measure of average achievement in key dimensions of human development for each country including life expectancy at birth, education index, and gross national income per capita (9), has demonstrated an impact on the incidence and mortality of prostate cancer (1-3).

Prostate-specific antigen (PSA) based screening has been adopted in several developed countries since 1990's, and downward trend of mortality rate from prostate cancer has been demonstrated in quite a few countries like United States of America (USA) (10), Canada (11), United Kingdom (UK) (12), and Japan (13). As current evidences on the benefit and harm of PSA screening from randomized controlled trials have not yet reached agreement (14-17), intense discussions on the pros and cons of PSA screening are still in progress, and corresponding recommendations for or against the PSA screening are changing frequently in different screening guidelines from a few studies (18-24). Changes in recommendations from guidelines posed obvious impact in the screening patterns and burden of prostate cancer, of which the most typical example is the recommendations from the US Preventive Services Task Force (USPSTF). In 2012, the USPSTF recommended against PSAbased screening for prostate cancer for all men regardless of age (25), whereafter several studies found that screening rates decreased while incidence of advanced prostate cancer increased (26-30). Then in 2018, the USPSTF recommended discussion of the potential benefits and harms of screening with their clinician for men aged 55-69 years (31). Subsequently, a few more screening guidelines have been published in support of PSA screening (32-34), whereas the impact on incidence and mortality of prostate cancer has not yet been determined.

Therefore, this study aimed to summarize the most upto-date global incidence and mortality for prostate cancer based on the GLOBOCAN 2020 database, and analyze temporal trends in incidence and mortality of prostate cancer from 2000 to 2019 by using consecutive data from the Global Burden of Disease (GBD) 2019 platform, which in combination are supposed to be useful for decision-making on the primary and secondary prevention strategy for prostate cancer.

\section{METHODS}

\section{Data Source}

Current status of incidence and mortality rates of prostate cancer in 2020 was analyzed by obtaining data of 185 countries or territories from the GLOBOCAN 2020 (35). Prostate cancer was coded C61 by using the International Classification of Disease (ICD, 10th revision, version 2010). Data on the HDI for each country was retrieved from the United Nations Development Program, from which HDIs in 2019 were available for 174 of the 185 countries (9). Finally, those 174 countries were included in the cross-sectional correlation analyses between the burden of prostate cancer and the HDI. According to the distributions of HDI, a four-quintile category of HDI was defined as follows: low HDI group for HDI $<0.550$, medium HDI group for HDI from 0.550 to 0.699 , high HDI group for HDI from 0.700 to 0.799 , and very high HDI group for HDI $\geq 0.800$.

To analyze the temporal trends of prostate cancer burden, data on the incidence and mortality data between 2000 and 2019 were obtained from the GBD 2019 platform (36). The GBD 2019 platform provided available data for 204 countries or territories, whereas the data quality for each country was spotty (37). As described in GBD 2019 (37), a simple starrating system from 0 to 5 to was developed to assess the quality of data available in a given country, defined by the percent well-certified data. A country was rated as a 3 star when the percent well-certified data $\geq 35 \%$, a 4 star for the percent well-certified data $\geq 65 \%$, and a 5 star for the percent wellcertified data $\geq 85 \%$. To assure the stability and reliability of the temporal trends as previous studies $(38,39)$, we only analyzed the data for countries with a 3-star or higher level in the GBD dataset, and a total of 89 countries were included in the final analysis (Table 1).

\section{Statistical Analysis}

All rates were adjusted by age and presented as age-standardized incidence rates (ASIRs) and age-standardized mortality rates (ASMRs). The standard population used was the Segi's standard population. The correlation between ASIR and ASMR and HDI level was analyzed using generalized additive models applied subject to non-linear associations. Trends in the incidence and mortality rates of prostate cancer were analyzed for each country by using the Joinpoint regression model (40). The average annual percent change (AAPC) was calculated for the full period from 2000 to 2019, and estimated annual percent change (EAPC) was calculated for each segment. The $\sim 95 \%$ confidential interval for AAPC and EAPC was also calculated by the empirical quantile method. The 2-tailed $t$-test was used for statistical inference and the null hypothesis of true AAPC or EAPC is 0 and the Bonferroni adjustment was used for multiple tests. A 2-sided $P<$ 0.05 was considered to be statistically significant. The Joinpoint regression analyses were conducted with Joinpoint Regression 
TABLE 1 | Estimated incidence and mortality of prostate cancer in the 89 countries in 2020.

\begin{tabular}{|c|c|c|c|c|c|c|c|c|}
\hline Continent & Country & HDI in 2019 & \multicolumn{3}{|c|}{ Incidence } & \multicolumn{3}{|c|}{ Mortality } \\
\hline \multirow[t]{2}{*}{ Africa } & Mauritius & 0.804 & 238 & 37.9 & 25.1 & 110 & 17.5 & 11.7 \\
\hline & South Africa & 0.709 & 13152 & 45 & 68.3 & 3896 & 13.3 & 22.1 \\
\hline \multirow[t]{17}{*}{ America } & Bahamas & 0.814 & 201 & 105.2 & 98.0 & 72.0 & 37.7 & 36.3 \\
\hline & Cuba & 0.783 & 6,369 & 113.3 & 57.6 & 3,409 & 60.6 & 24.7 \\
\hline & Dominican Republic & 0.756 & 4,808 & 88.7 & 88.7 & 2,228 & 41.1 & 35.0 \\
\hline & Jamaica & 0.734 & 1,561 & 106.2 & 87.6 & 844 & 57.4 & 39.4 \\
\hline & Saint Lucia & 0.759 & 135 & 149.3 & 103.2 & 54 & 59.7 & 32.6 \\
\hline & Trinidad and Tobago & 0.796 & 884 & 127.9 & 89.2 & 403 & 58.3 & 38.9 \\
\hline & Guatemala & 0.663 & 2760 & 31.3 & 49.0 & 786 & 8.9 & 12.0 \\
\hline & Mexico & 0.779 & 2,6742 & 42.4 & 42.2 & 7457 & 11.8 & 10.6 \\
\hline & Nicaragua & 0.66 & 1,063 & 32.6 & 44.7 & 304 & 9.3 & 12.1 \\
\hline & Panama & 0.815 & 1,493 & 69.1 & 60.9 & 406 & 18.8 & 13.8 \\
\hline & Argentina & 0.845 & 11,686 & 53.0 & 42.0 & 3,964 & 18 & 12.2 \\
\hline & Brazil & 0.765 & 97,278 & 93.1 & 78.0 & 18,345 & 17.6 & 13.7 \\
\hline & Chile & 0.851 & 8,157 & 86.5 & 56.7 & 2,96 & 24.4 & 14.0 \\
\hline & Colombia & 0.767 & 14,460 & 57.9 & 49.8 & 3,846 & 15.4 & 11.9 \\
\hline & Ecuador & 0.759 & 3,249 & 36.8 & 35.7 & 1,272 & 14.4 & 12.5 \\
\hline & Guyana & 0.682 & 271 & 68.5 & 71.8 & 90 & 22.8 & 21.9 \\
\hline & United States of America & 0.926 & 209,512 & 127.9 & 72 & 32,438 & 19.8 & 8.2 \\
\hline \multirow[t]{16}{*}{ Asia } & China & 0.761 & 115,426 & 15.6 & 10.2 & 51,094 & 6.9 & 4.6 \\
\hline & Japan & 0.919 & 106,139 & 171.9 & 51.8 & 13,426 & 21.7 & 4.5 \\
\hline & Korea, Republic of & 0.916 & 13,873 & 54.1 & 27.3 & 2,200 & 8.6 & 4.1 \\
\hline & Brunei Darussalam & 0.838 & 40 & 17.6 & 23.0 & 8 & 3.5 & 5.0 \\
\hline & Philippines & 0.718 & 8,242 & 15.0 & 23.4 & 3,164 & 5.7 & 10.8 \\
\hline & Singapore & 0.938 & 1,846 & 60.3 & 34.3 & 371 & 12.1 & 7.3 \\
\hline & Thailand & 0.777 & 8,630 & 25.4 & 14.6 & 3,837 & 11.3 & 5.9 \\
\hline & Kazakhstan & 0.825 & 1,028 & 11.3 & 12.8 & 532 & 5.8 & 6.8 \\
\hline & Kyrgyzstan & 0.697 & 133 & 4.1 & 7.5 & 78 & 2.4 & 4.5 \\
\hline & Sri Lanka & 0.782 & 896 & 8.7 & 6.3 & 364 & 3.5 & 2.6 \\
\hline & Tajikistan & 0.668 & 80 & 1.7 & 3.2 & 43 & 0.89 & 1.8 \\
\hline & Turkmenistan & 0.715 & 118 & 4 & 6.3 & 63 & 2.1 & 3.3 \\
\hline & Uzbekistan & 0.72 & 929 & 5.6 & 8.5 & 456 & 2.7 & 4.2 \\
\hline & Armenia & 0.776 & 892 & 64 & 45.8 & 346 & 24.8 & 16.3 \\
\hline & Azerbaijan & 0.756 & 565 & 11.2 & 12.1 & 218 & 4.3 & 5.0 \\
\hline & Bahrain & 0.852 & 51 & 4.6 & 13.3 & 12 & 1.1 & 4.5 \\
\hline
\end{tabular}


TABLE 1 | Continued

\begin{tabular}{|c|c|c|c|c|c|c|c|c|}
\hline Continent & Country & HDI in 2019 & \multicolumn{3}{|c|}{ Incidence } & \multicolumn{3}{|c|}{ Mortality } \\
\hline & Israel & 0.919 & 3,290 & 76.4 & 56.1 & 531 & 12.3 & 6.7 \\
\hline & Kuwait & 0.806 & 255 & 9.8 & 19.6 & 52 & 2 & 6.6 \\
\hline \multirow[t]{27}{*}{ Europe } & Belarus & 0.823 & 4,076 & 92.6 & 58.4 & 1,024 & 23.3 & 14.6 \\
\hline & Bulgaria & 0.816 & 4,983 & 147.7 & 63.2 & 1,215 & 36 & 13.4 \\
\hline & Czechia & 0.9 & 9,117 & 172.9 & 83.0 & 14,67 & 27.8 & 11.0 \\
\hline & Hungary & 0.854 & 6,234 & 135.6 & 66.5 & 1,481 & 32.2 & 13.9 \\
\hline & Poland & 0.880 & 18,079 & 98.6 & 47.5 & 7,074 & 38.6 & 16.6 \\
\hline & Slovakia & 0.860 & 2,501 & 94.1 & 50.8 & 1,083 & 40.7 & 20.9 \\
\hline & Ukraine & 0.779 & 11,361 & 56.1 & 33.2 & 4,219 & 20.8 & 11.9 \\
\hline & Denmark & 0.94 & 4,760 & 165.3 & 75.6 & 1,392 & 48.3 & 15.9 \\
\hline & Estonia & 0.892 & 1,228 & 195.4 & 102.1 & 331 & 52.7 & 21.8 \\
\hline & Finland & 0.938 & 5,710 & 209 & 82.1 & 914 & 33.5 & 10.2 \\
\hline & Iceland & 0.949 & 220 & 128.4 & 68.3 & 60 & 35 & 13.7 \\
\hline & Ireland & 0.955 & 4,503 & 183.7 & 110.7 & 569 & 23.2 & 10.3 \\
\hline & Latvia & 0.866 & 1,531 & 176.1 & 87.6 & 405 & 46.6 & 19.9 \\
\hline & Lithuania & 0.882 & 2,237 & 177.5 & 94.5 & 564 & 44.8 & 18.4 \\
\hline & Malta & 0.895 & 336 & 151.7 & 60.2 & 53 & 23.9 & 8.1 \\
\hline & North Macedonia & 0.774 & 785 & 75.3 & 42.6 & 301 & 28.9 & 15.6 \\
\hline & Portugal & 0.864 & 6,759 & 140.1 & 59.6 & 1,917 & 39.7 & 10.6 \\
\hline & Serbia & 0.806 & 3,144 & 73.5 & 33.4 & 1,251 & 29.2 & 12 \\
\hline & Slovenia & 0.917 & 1,834 & 177.2 & 79.3 & 451 & 43.6 & 14.9 \\
\hline & Spain & 0.904 & 34,613 & 150.6 & 70.6 & 5,798 & 25.2 & 7.3 \\
\hline & Austria & 0.922 & 6,088 & 137.1 & 64.9 & 1,378 & 31 & 10.1 \\
\hline & Belgium & 0.931 & 8,163 & 142.1 & 68.1 & 1,670 & 29.1 & 9.2 \\
\hline & France & 0.901 & 66,070 & 209.2 & 99 & 9,060 & 28.7 & 8.4 \\
\hline & Germany & 0.947 & 67,959 & 164.1 & 66 & 15,507 & 37.4 & 10.6 \\
\hline & Luxembourg & 0.916 & 392 & 123.8 & 71.3 & 63 & 19.9 & 8.8 \\
\hline & Switzerland & 0.955 & 6,705 & 156.2 & 75.6 & 1,299 & 30.3 & 9.4 \\
\hline & The Netherlands & 0.944 & 14,580 & 170.8 & 73.9 & 2,976 & 34.9 & 11.5 \\
\hline \multirow[t]{2}{*}{ Oceania } & Australia & 0.944 & 16,973 & 133.7 & 72.5 & 3,455 & 27.2 & 10 \\
\hline & New Zealand & 0.931 & 3,938 & 166.1 & 92.9 & 756 & 31.9 & 12.3 \\
\hline
\end{tabular}

$C R$, crude rate; ASR, age-standardized rate; $H D I$, human development index. 
Program version 4.9.0.0 (National Cancer Institute, Bethesda, America) (41).

\section{RESULTS}

\section{Prostate Cancer Incidence and Mortality in 2020}

The incidence and mortality of prostate cancer in 2020 of the major countries are shown in Table 1. Globally, more than 1.4 million new prostate cancer cases were diagnosed in 2020. The crude incidence rate was 36.0 per 100,000 males and the ASIR was 30.7 per 100,000 males. Data by continents in Figure 1 showed that, ASIRs in Europe, Latin America and the Caribbean, Northern America and Oceania exceeded 59 per 100,000 males, while ASIRs in Africa and Asia were lower than 30 per 100,000 males. However, the regional distribution of ASMR was quite different, with the highest rate in Africa, followed by Latin America and the Caribbean, Europe, Oceania, Northern America and Asia.

ASIRs substantially vary more than 123-fold among 174 countries, wherein the highest ASIR was 110.7 per 100,000 males in Ireland from Northern Europe while the lowest ASIR was 0.9 per 100,000 males in Bhutan from South-Central Asia. Similarly, ASMRs varied by more than 77 -fold among 174 countries, from the lowest ASMR of 0.54 per 100,000 males in Bhutan from South-Central Asia to the highest ASMR of 41.7 per 100,000 males in Zimbabwe from Eastern Africa, in which the crude mortality rate was only 12.2 per 100,000 (Table 1).

Through ecological correlation analysis presented in Figure 2, we found that a positive correlation between the incidence of prostate cancer and HDI $\left(\mathrm{R}^{2}=0.327, P<0.001\right)$, with ASIRs in countries with a very high HDI more than twice greater than those in countries with a low HDI, while a negative correlation between the ASMRs of prostate cancer and HDI $\left(\mathrm{R}^{2}=0.05, P<\right.$ 0.001, Figure 2).

\section{Trend Patterns From 2000 to 2019}

By grouping according to the changing trends in the ASIR and ASMR of prostate cancer of 89 countries, six subgroups were divided, including significantly increasing ASIR $(P<0.05)$ and $\operatorname{ASMR}(P<0.05)$ in 19 countries (Group A), significantly increasing $\operatorname{ASIR}(P<0.05)$ and stable $\operatorname{ASMR}(P \geq 0.05)$ in 21 countries (Group B), increasing ASIR $(P<0.05)$ but decreasing $\operatorname{ASMR}(P<0.05)$ in 25 countries (Group C), stable ASIR $(P \geq$ $0.05)$ and $\operatorname{ASMR}(P \geq 0.05)$ in 4 countries (Group D), stable $\operatorname{ASIR}(P \geq 0.05)$ but decreasing $\operatorname{ASMR}(P<0.05$, $)$ in 11 countries (Group E), and decreasing ASIR $(P<0.05)$ and ASMR $(P<0.05)$ in 9 countries (Group F; Table 2).

In the past two decades, an increasing trend of ASIR for prostate cancer was observed in 65 countries, nearly all countries had high or very high HDI except Tajikistan, and the AAPCs ranged from $0.23 \%$ (Argentina) to $4.54 \%$ (Republic of Moldova). Meanwhile, significantly increasing mortality trends were also observed in 19 of the 65 countries, with the AAPCs ranging from $0.36 \%$ (Suriname) to $3.63 \%$ (Georgia) while significantly decreasing mortality trends were also observed in 25 of the 65 countries, with AAPCs ranging from $-1.85 \%$ (Ireland) to
$-0.32 \%$ (South Africa). In addition, ASIR and ASMR have been significantly decreasing from 2000 to 2019 in nine countries with a very high HDI, including the Austria, Canada, France, Iceland, Luxembourg, New Zealand, Sweden, Switzerland, and United States of America (Tables 3, 4; Figure 3).

\section{Trend Patterns in Most Recent Period}

However, in the latest period, the magnitudes of increase for ASIRs and decrease for ASMRs were attenuated or even reversed. ASIRs have been significantly increasing in only 44 countries in the most recent period compared with 65 countries in the full period, and ASMRs have been significantly decreasing in 32 countries in the most recent period compared with 45 countries in the full period (Figure 4). For instance, the AAPC of ASIR in the United States of America was $-0.69 \%$ (95\% CI: -0.92 to $-0.46 \%$ ) from 2000 to 2019 , while the AAPC was $0.49 \%$ (95\% CI: $0.06-0.91 \%$ ) from 2015 to 2019. And the AAPC of ASMR was $-1.22 \%$ (95\% CI: -1.38 to $-1.06 \%$ ) from 2000 to 2019 but it was $0.48 \%$ (95\% CI: $0.33-0.63 \%$ ) from 2015 to 2019 (Tables 3, 4).

\section{DISCUSSION}

In this study, we carried out a comprehensive analysis to examine the global status and temporal trends in prostate cancer incidence and mortality in 89 countries, and the results showed that HDI was positively correlated with ASIRs and negatively correlated with ASMRs. In the past decades, ASIRs have been increasing in 65 countries, stable in 15 countries and decreasing in 9 countries, and ASMRs have been increasing in 19 countries, stable in 25 countries and decreasing in 45 countries. However, in the latest period, the magnitudes of increase for ASIRs and decrease for ASMRs were attenuated or even reversed.

Globally, tremendously international variations exist in the prostate cancer incidence rates, including higher incidence rates of prostate cancer in Northern America, Europe, and Oceania, lower rates in Africa and Asia. In addition, a positive correlation between the incidence of prostate cancer and HDI, which is consistent with previous studies $(2,42,43)$. The occurrence and progression of prostate cancer experienced complicated process under both genetic and environmental influences. Except for age, which was adjusted in our study, race disparity was documented in a few studies. The AISRs in several countries in Caribbean like Barbados, Saint Lucia, Bahamas and Trinidad and Tobago exceeded 89 per 100,000, which could be partly attributed to the African ancestry $(29,44,45)$. Similar race disparity was also determined in USA, the incidence rate of prostate cancer in the Black men is nearly 1.7 times higher than that in White men, while the relative survival rate is lower for Black men than White men $(46,47)$.

Though PSA-based screening is still controversial, widely adopted PSA screening may play an important role in the increasing ASIRs in countries with very high or high HDI, like USA, UK, Canada, Australia, Swiss, Sweden, Japan. Results from three representative trials have documented the effect of PSA screening in increasing the incidence of prostate cancer, by $12 \%$ from the Prostate, Lung, Colorectal and 


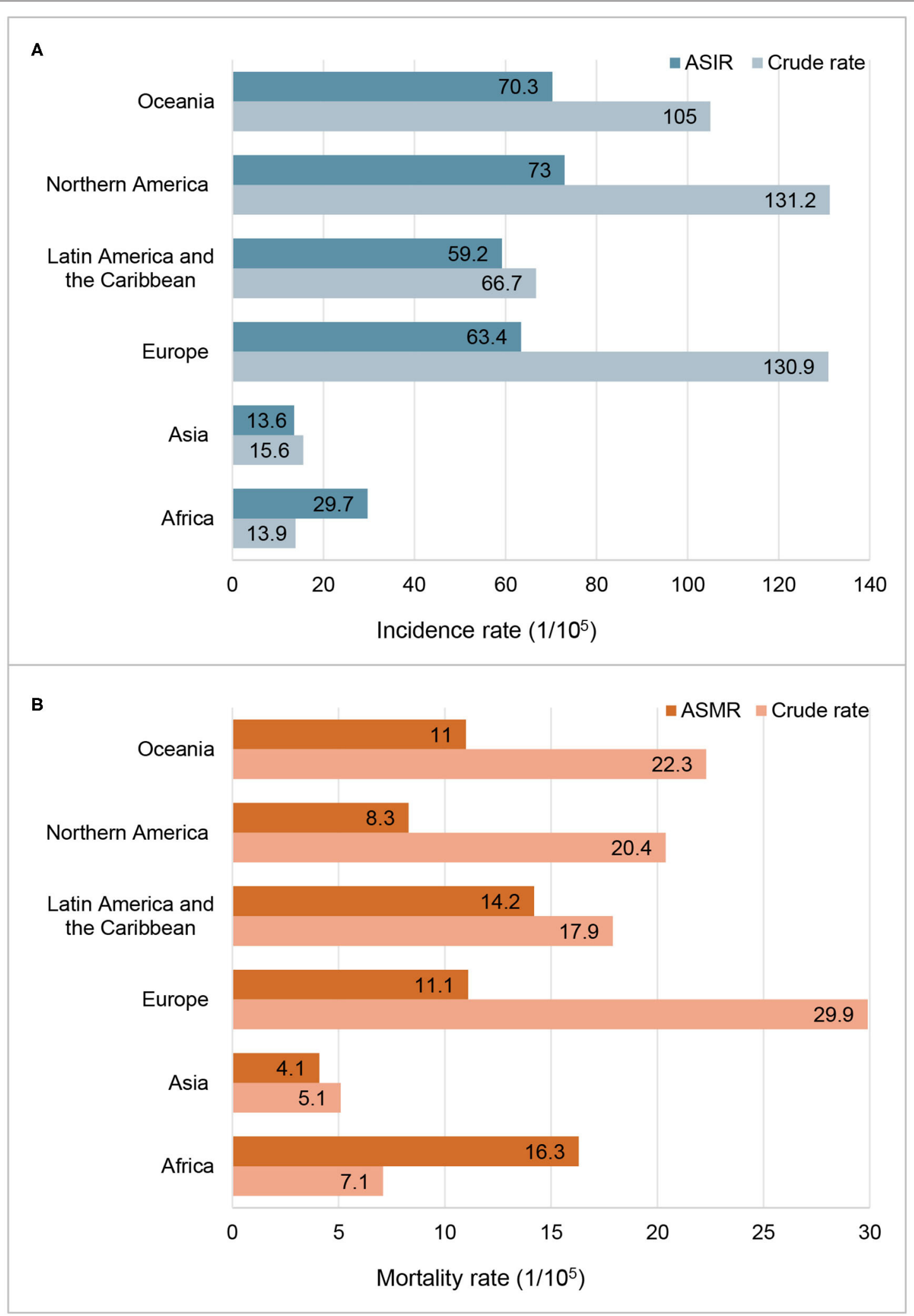

FIGURE 1 | Incidence and mortality of prostate cancer in 2020 by continent. (A) Incidence rate; (B) Mortality rate; ASIR, age-standardized incidence rate; ASMR, age-standardized mortality rate. 


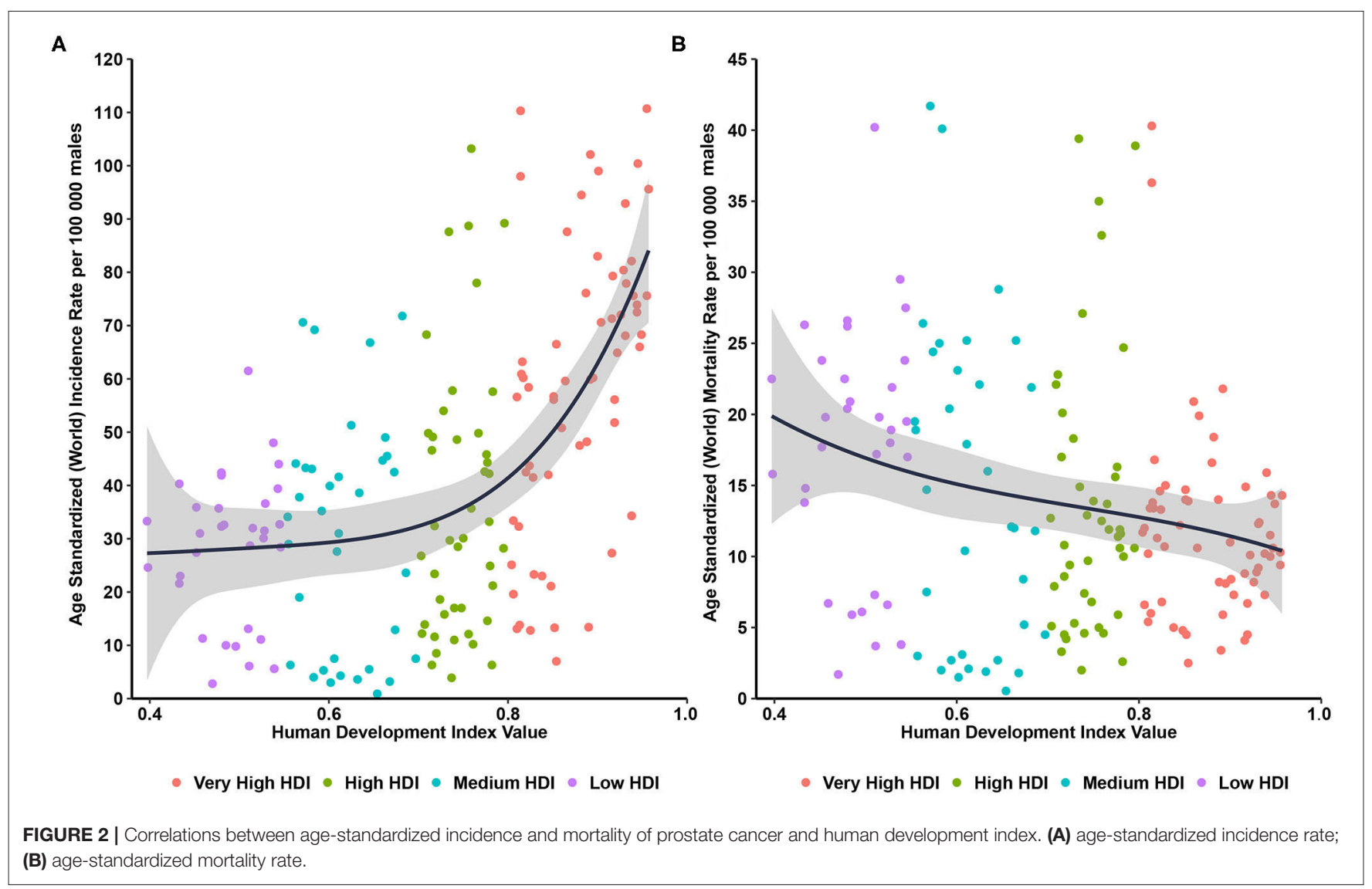

Ovarian (PLCO) screening trial (48), 91\% from the European Randomized Study of Screening for Prostate Cancer (ERSPC) (49), and 51\% from the Göteborg Randomized Populationbased Prostate Cancer Screening Trial (50). The effect of overdiagnosis of prostate cancer from PSA screening has been discussed in both population-based and modeling studies, ranging from 1.7 to $67 \%$ (16). However, increasing trends of ASIRs were also found in several Asia countries without national organized screening programs, like China, Thailand, Georgia and Korea. Reasons for the increase are unclear, and a few studies suggested some potential risk factors, including increasing prevalence of obesity and diabetes mellitus, westernized diet, and inadequate physical activity (51-55). Taking China for example, the prevalence of overweight and obesity has been increasing from 29.9 to $50.7 \%$ in the past two decades, and it was expected to reach $65.3 \%$ by 2030 (56).

Unlike ASIR, the ASMR decreased with the HDI, and ASMR continued to decrease or kept stable in 70 out of 89 countries, which reflects the effect of widespread PSA screening, active surveillance of high-risk population and improved treatment regimens for prostate cancer. As previous studies stated (1-3), PSA screening have been adopted since 1990's in quite a few countries in America, Europe, and Australia, which detects more prostate cancer in localized stage, resulting in the downward of advanced stage of prostate cancer, and the five-year survival rates of prostate cancer in these countries have been approaching $100 \%$ (57). Evidence from randomized trials have also demonstrated the effect of PSA screening in mortality reduction of prostate cancer, by $20 \%$ at 16 year of follow-up from ERSPS (49) and by $35 \%$ at 18 year of follow-up from Göteborg screening trial (50). In addition, for several countries in Asia and Africa, the ASMR continued to decrease, and the corresponding survival rates have been increasing in the past two decades. Taking China for example, the relative survival rate of prostate cancer rose from $53.8 \%$ in $2003-2005$ to $66.4 \%$ in $2012-2015$ (58), and no national prostate cancer screening program was implemented during the period. Notably, ASMRs of prostate cancer have been increasing in 19 counties, most from Asia and Central and Eastern Europe. The underlying reasons are unclear, and the increasing risk factors for aggressive prostate cancer might partly explain, such as increased intake of energy, animal fat and red meats $(2,52)$.

Notably, in USA, Canada, and some countries in Europe, the ASIRs are decreasing and ASMRs are increasing. It is still undefined whether the recommendations against the PSA screening from several guidelines play the crucial role. In USA, the introduction of PSA into the population in the early 1990, and then prostate cancer incidence and mortality has been decreasing (10). Because of concerns about over detection, treatment morbidity, and limited short-term absolute mortality benefit, 
TABLE 2 | Patterns of trends in incidence and mortality for prostate cancer from 2000 to 2019 among 89 countries.

\begin{tabular}{|c|c|c|c|c|}
\hline Group & Incidence ${ }^{a}$ & Mortality ${ }^{a}$ & $\begin{array}{l}\text { Number of } \\
\text { countries }\end{array}$ & List of country (AAPC of incidence, AAPC of mortality, \%) \\
\hline A & Increasing & Increasing & 19 & $\begin{array}{l}\text { Armenia }(2.66,1) \text {, Azerbaijan }(1.75,0.43) \text {, Brunei Darussalam }(2.74,1.89) \text {, Bulgaria }(3.11 \text {, } \\
\text { 2.17), Croatia }(2.26,0.4) \text {, Cuba }(1.97,0.54) \text {, Estonia }(3.79,0.48) \text {, Georgia }(4.04,3.63) \text {, } \\
\text { Kazakhstan }(2.88,0.65) \text {, Latvia }(2.99,0.97) \text {, Lithuania }(2.12,0.52) \text {, North Macedonia }(2.18 \text {, } \\
\text { 0.72), Republic of Moldova }(4.77,2.6) \text {, Romania }(2.81,0.54) \text {, Russian Federation }(3.57,0.87) \text {, } \\
\text { Serbia }(2.63,0.91) \text {, Suriname }(1.24,0.36) \text {, Tajikistan }(1.37,0.75) \text {, Uzbekistan }(1.42,0.52)\end{array}$ \\
\hline B & Increasing & Stable & 21 & $\begin{array}{l}\text { Albania }(1.8,0.05) \text {, Bahrain }(1.73,-0.26) \text {, Barbados }(0.75,-0.17) \text {, Belarus }(3.21,0.26) \text {, Costa } \\
\text { Rica }(1.56,-0.19) \text {, Dominican Republic }(0.69,-0.5) \text {, Ecuador }(1.52,0.14) \text {, El Salvador }(1.67 \text {, } \\
-0.04) \text {, Kuwait }(2.34,0.53) \text {, Nicaragua }(3.03,0.26) \text {, Paraguay }(1.82,0.1) \text {, Philippines }(0.58 \text {, } \\
0.11) \text {, Saint Lucia }(0.42,-0.17) \text {, Singapore }(1.4,-1.14) \text {, Slovakia }(1.97,-0.08) \text {, Sri Lanka } \\
(2.48,0.05) \text {, Syrian Arab Republic }(1.23,-0.13) \text {, Turkey }(2.36,-0.72) \text {, Turkmenistan }(1.64 \text {, } \\
\text { 0.29), Ukraine (1.56, 0.23), Venezuela, Bolivarian Republic of }(1.45,0.17)\end{array}$ \\
\hline C & Increasing & Decreasing & 25 & 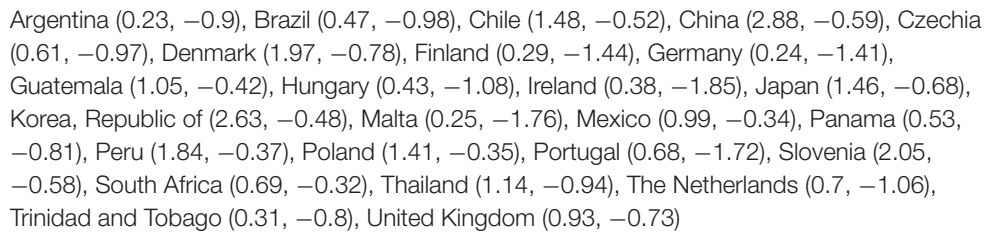 \\
\hline $\mathrm{D}$ & Stable & Stable & 4 & Bahamas $(0.04,-0.16)$, Colombia $(0.8,-1.31)$, Jamaica $(0.55,0.23)$, Kyrgyzstan $(0.35,-0.95)$ \\
\hline$E$ & Stable & Decreasing & 11 & $\begin{array}{l}\text { Australia }(0.04,-1.1) \text {, Belgium }(-0.11,-1.75) \text {, Belize }(0.06,-0.91) \text {, Greece }(-0.2,-1.3) \text {, } \\
\text { Guyana }(0.08,-0.33) \text {, Israel }(-0.22,-1.99) \text {, Italy }(-0.11,-1.54) \text {, Mauritius }(0.23,-0.68) \text {, } \\
\text { Norway }(0.12,-1.3) \text {, Spain }(-0.06,-1.66) \text {, Uruguay }(0.29,-0.8)\end{array}$ \\
\hline $\mathrm{F}$ & Decreasing & Decreasing & 9 & $\begin{array}{l}\text { Austria }(-0.42,-1.73) \text {, Canada }(-1.5,-2.19) \text {, France }(-0.29,-2.19) \text {, Iceland }(-0.63,-1.53) \text {, } \\
\text { Luxembourg }(-0.52,-2.21) \text {, New Zealand }(-0.43,-1.6) \text {, Sweden }(-0.48,-1.53) \text {, } \\
\text { Switzerland }(-0.88,-1.69) \text {, United States of America }(-0.69,-1.22)\end{array}$ \\
\hline
\end{tabular}

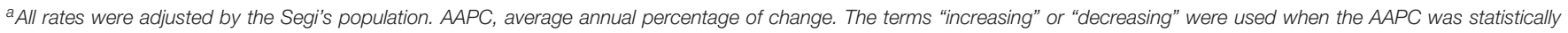
significant $(P<0.05)$; otherwise, the term "stable" was used.

the US Preventive Services Task Force (USPSTF) recommended against PSA screening for men aged 75 years and older in 2008 and for all ages in $2012(25,59)$, Thereafter, the screening rates of PSA have been continued to be decreasing in men aged 50 years and older $(10,26)$. After a decline in PSA test usage, there has been an increased burden of late-stage disease, and the decline in prostate cancer mortality has leveled off (10). Modeling studies demonstrated that newly diagnosed metastatic prostate cancer cases increased by $44 \%-60 \%$ in the 5 years after the 2012 USPSTF recommendation (30). Similar inversions in incidence and mortality of prostate cancer were also documented by previous studies, along with steady declines of willingness in physicians and general population toward PSA screening test after the changes in the USPSTF's recommendations in Canada and Australia $(27,60)$. In 2018, the USPSTF recommended discussion of the potential benefits and harms of screening with their clinician for men aged 55-69 years (31). Subsequently, a few more screening guidelines have been published in support of PSA screening (32-34). Herein, more studies are needed to determine the effect of positive recommendations of PSA screening. In addition, with the advent of personalized medicine and development of multi-omics analysis, a few genomic, epigenomic, and transcriptomic biomarkers have been identified to be potentially associated with prostate cancer risk, while the utility of these biomarkers in the screening and surveillance is unclear, and the head-to-head comparison with PSA is lacking (61-64).

\section{Strengths and Limitations}

The main strength of our study is the effective integration of two public databases with high-quality, thus to provide the latest status and temporal changes of prostate cancer throughout the world. However, some limitations are noteworthy when interpreting the results from our study. First, the availability and quality of original data in the GBD platform were inconsistent for different countries, and some data were indirectly estimated from modeling strategy (37). Second, though we separately analyzed the current status and temporal trends by using the GLOBOCAN 2020 and GBD 2019 platform, respectively, the differences still existed for two platform in data source, analysis method and covariates for modeling epidemiologic data (65). Third, most countries included in our studies had high or very high HDI, which might apparently limit the representativeness and extrapolation of the results. Forth, we could not acquire the accurate information of prostate cancer screening program in individual country, including the population coverage, screening rates, form of implementation and health effectiveness, which 
TABLE 3 | Trend analysis of age-standardized incidence for prostate cancer from 2000 to 2019.

\begin{tabular}{|c|c|c|c|c|c|c|c|c|c|c|c|c|c|c|}
\hline \multirow[t]{2}{*}{ Country } & \multirow[t]{2}{*}{ AAPC } & \multirow[t]{2}{*}{ Range } & \multicolumn{3}{|c|}{ Trend1 } & \multicolumn{3}{|c|}{ Trend2 } & \multicolumn{3}{|c|}{ Trend3 } & \multicolumn{3}{|c|}{ Trend4 } \\
\hline & & & Period & EAPC & Range & Period & EAPC & Range & Period & EAPC & Range & Period & EAPC & Range \\
\hline Albania & $1.8^{\star}$ & $1.17-2.42$ & $2000-13$ & $1.44^{\star}$ & $1.19-1.69$ & 2013-16 & $4.06^{\star}$ & $0.17-8.1$ & 2016-19 & 1.12 & $-0.65-2.92$ & & & \\
\hline Argentina & $0.23^{*}$ & $0.08-0.38$ & 2000-06 & $1.09^{\star}$ & $0.77-1.4$ & 2006-15 & $-0.94^{*}$ & -1.13 to -0.76 & 2015-19 & $1.61^{*}$ & $1.1-2.12$ & & & \\
\hline Armenia & $2.66^{*}$ & $2.44-2.88$ & 2000-11 & $3.24^{\star}$ & $2.93-3.54$ & 2011-19 & $1.86^{\star}$ & $1.47-2.26$ & & & & & & \\
\hline Australia & 0.04 & $-0.38-0.46$ & 2000-04 & $4.12^{\star}$ & $2.99-5.27$ & 2004-08 & 0.58 & $-0.97-2.15$ & 2008-14 & $-2.94^{*}$ & -3.58 to -2.29 & 2014-19 & 0.04 & $-0.6-0.68$ \\
\hline Austria & $-0.42^{*}$ & -0.58 to -0.26 & 2000-04 & 0.24 & $-0.35-0.82$ & 2004-12 & $-1.07^{\star}$ & -1.3 to -0.83 & 2012-19 & -0.05 & $-0.28-0.18$ & & & \\
\hline Azerbaijan & $1.75^{\star}$ & $1.49-2.02$ & 2000-09 & $2.39^{\star}$ & $2.12-2.66$ & 2009-17 & $1.56^{\star}$ & $1.24-1.89$ & 2017-19 & -0.35 & $-2.45-1.79$ & & & \\
\hline Bahamas & 0.04 & $-0.08-0.17$ & 2000-19 & 0.04 & $-0.08-0.17$ & & & & & & & & & \\
\hline Bahrain & $1.73^{\star}$ & $0.93-2.54$ & 2000-03 & $7.82^{\star}$ & $3.97-11.8$ & 2003-09 & 1.3 & $-0.03-2.66$ & 2009-13 & $-2.96^{*}$ & -5.41 to -0.46 & 2013-19 & $2.42^{\star}$ & $1.75-3.1$ \\
\hline Barbados & $0.75^{\star}$ & $0.53-0.96$ & 2000-04 & $1.1^{\star}$ & $0.39-1.81$ & 2004-17 & $-0.28^{*}$ & -0.39 to -0.16 & 2017-19 & $6.89^{\star}$ & $5.15-8.65$ & & & \\
\hline Belarus & $3.21^{\star}$ & $2.25-4.19$ & 2000-05 & $1.94^{\star}$ & $0.09-3.83$ & 2005-10 & $5.56^{\star}$ & $3.06-8.12$ & 2010-17 & $3.37^{\star}$ & $2.23-4.52$ & 2017-19 & 0.11 & $-5.57-6.14$ \\
\hline Belgium & -0.11 & $-0.48-0.26$ & 2000-04 & $4.52^{*}$ & $3.6-5.45$ & 2004-08 & 0.06 & $-1.24-1.39$ & $2008-13$ & $-4.54^{*}$ & -5.35 to -3.73 & 2013-19 & $0.54^{*}$ & $0.09-0.99$ \\
\hline Belize & 0.06 & $-0.71-0.83$ & 2000-03 & -1.54 & $-3.76-0.74$ & 2003-06 & 2.14 & $-2.17-6.64$ & $2006-10$ & $-2.14^{*}$ & -4.09 to -0.15 & 2010-19 & $0.9^{*}$ & $0.58-1.21$ \\
\hline Brazil & $0.47^{\star}$ & $0.2-0.73$ & 2000-04 & $2.28^{\star}$ & $1.73-2.82$ & 2004-07 & 0.65 & $-0.88-2.2$ & 2007-17 & $-0.57^{*}$ & -0.7 to -0.45 & 2017-19 & $1.85^{\star}$ & $0.61-3.1$ \\
\hline $\begin{array}{l}\text { Brunei } \\
\text { Darussalam }\end{array}$ & $2.74^{*}$ & $2.24-3.25$ & 2000-05 & $6.19^{\star}$ & $4.62-7.78$ & 2005-13 & $2.71^{*}$ & $1.99-3.43$ & 2013-19 & 0 & $-0.77-0.77$ & & & \\
\hline Bulgaria & $3.11^{\star}$ & $2.89-3.34$ & 2000-06 & $5.65^{\star}$ & $5.33-5.96$ & 2006-10 & $3.78^{\star}$ & $2.99-4.57$ & 2010-14 & $2.58^{*}$ & $1.85-3.3$ & 2014-19 & 0.06 & $-0.24-0.36$ \\
\hline Canada & $-1.5^{\star}$ & -1.91 to -1.08 & 2000-03 & 0.43 & $-0.84-1.72$ & 2003-11 & $-3.85^{\star}$ & -4.17 to -3.53 & 2011-14 & -2.42 & $-4.85-0.08$ & 2014-19 & $1.78^{\star}$ & $1.24-2.31$ \\
\hline Chile & $1.48^{*}$ & $1.05-1.91$ & 2000-04 & $2.89^{\star}$ & $2.03-3.76$ & 2004-07 & 0.71 & $-1.69-3.17$ & $2007-11$ & $2.74^{\star}$ & $1.61-3.88$ & 2011-19 & $0.45^{\star}$ & $0.24-0.66$ \\
\hline China & $2.88^{*}$ & $2.57-3.18$ & 2000-07 & $3.27^{*}$ & $2.97-3.57$ & $2007-10$ & $4.41^{*}$ & $2.54-6.32$ & $2010-16$ & $1.79^{\star}$ & $1.44-2.15$ & 2016-19 & $2.63^{*}$ & $1.94-3.32$ \\
\hline Colombia & 0.8 & $-0.94-2.58$ & 2000-02 & 5.61 & $-4.82-17.18$ & 2002-05 & -4.23 & $-13.11-5.56$ & 2005-16 & $0.7^{*}$ & $0.01-1.39$ & 2016-19 & 3.25 & $-0.46-7.1$ \\
\hline Costa Rica & $1.56^{\star}$ & $1.35-1.78$ & $2000-19$ & $1.56^{\star}$ & $1.35-1.78$ & & & & & & & & & \\
\hline Croatia & $2.26^{*}$ & $1.96-2.56$ & 2000-05 & $4.92^{\star}$ & $4.06-5.79$ & 2005-15 & $1.89^{\star}$ & $1.6-2.19$ & 2015-19 & -0.08 & $-0.95-0.81$ & & & \\
\hline Cuba & $1.97^{\star}$ & $1.78-2.15$ & 2000-06 & $2.85^{\star}$ & $2.29-3.42$ & 2006-19 & $1.56^{\star}$ & $1.42-1.7$ & & & & & & \\
\hline Czechia & $0.61^{*}$ & $0.37-0.85$ & 2000-04 & $3.33^{*}$ & $2.62-4.05$ & 2004-09 & $1.86^{\star}$ & $1.24-2.49$ & 2009-15 & -1.76 & -2.16 to -1.36 & 2015-19 & -0.04 & $-0.6-0.52$ \\
\hline Denmark & $1.97^{\star}$ & $1.59-2.36$ & 2000-04 & $8.26^{*}$ & $7.07-9.46$ & 2004-09 & $4.22^{\star}$ & $3.27-5.17$ & 2009-14 & -2.6 & -3.42 to -1.77 & 2014-19 & -0.42 & $-1.01-0.18$ \\
\hline $\begin{array}{l}\text { Dominican } \\
\text { Republic }\end{array}$ & $0.69^{\star}$ & $0.3-1.09$ & 2000-06 & $2.78^{*}$ & $2.35-3.21$ & 2006-09 & $-2.56^{\star}$ & -4.73 to -0.33 & 2009-13 & $2.15^{\star}$ & $1.07-3.25$ & 2013-19 & $-0.68^{\star}$ & $\begin{array}{c}-1.01 \text { to } \\
-0.34\end{array}$ \\
\hline Ecuador & $1.52^{\star}$ & $1.19-1.85$ & 2000-07 & $3.54^{\star}$ & $2.68-4.41$ & 2007-19 & $0.36^{\star}$ & $0.07-0.64$ & & & & & & \\
\hline El Salvador & $1.67^{\star}$ & $0.78-2.57$ & 2000-02 & 0.18 & $-6.07-6.86$ & 2002-06 & $4.9^{*}$ & $1.84-8.06$ & 2006-13 & $-1.32^{*}$ & -2.24 to -0.39 & 2013-19 & $3.6^{\star}$ & $2.74-4.47$ \\
\hline Estonia & $3.79^{\star}$ & $3.51-4.08$ & 2000-08 & $7.08^{\star}$ & $6.65-7.51$ & 2008-15 & $2.79^{\star}$ & $2.3-3.29$ & 2015-19 & -0.81 & $-1.64-0.03$ & & & \\
\hline Finland & $0.29^{\star}$ & $0.09-0.48$ & 2000-04 & $2.92^{\star}$ & $2.18-3.68$ & 2004-14 & $-0.86^{\star}$ & -1.05 to -0.68 & 2014-19 & $0.51^{\star}$ & $0.08-0.95$ & & & \\
\hline France & $-0.29^{*}$ & -0.56 to -0.02 & 2000-03 & $3.84^{*}$ & $2.78-4.91$ & 2003-07 & -0.24 & $-1.21-0.73$ & $2007-13$ & $-3.08^{*}$ & -3.5 to -2.66 & 2013-19 & $0.49^{\star}$ & $0.16-0.81$ \\
\hline Georgia & $4.04^{*}$ & $3.56-4.53$ & 2000-05 & $10.84^{*}$ & $9.41-12.29$ & 2005-12 & $3.22^{*}$ & $2.35-4.1$ & 2012-19 & 0.23 & $-0.4-0.86$ & & & \\
\hline Germany & $0.24^{\star}$ & $0.02-0.46$ & 2000-04 & $2.45^{\star}$ & $2.01-2.88$ & 2004-09 & $0.47^{\star}$ & $0.07-0.87$ & 2009-12 & $-1.85^{\star}$ & -3.07 to -0.61 & 2012-19 & $-0.27^{*}$ & $\begin{array}{c}-0.43 \text { to } \\
-0.1\end{array}$ \\
\hline Greece & -0.2 & $-0.45-0.05$ & 2000-04 & $1.56^{*}$ & $0.76-2.36$ & $2004-16$ & $-1.11^{*}$ & -1.28 to -0.95 & 2016-19 & 1.16 & $-0.1-2.44$ & & & \\
\hline Guatemala & $1.05^{\star}$ & $0.61-1.49$ & 2000-05 & $3.72^{\star}$ & $2.78-4.67$ & $2005-12$ & $0.57^{\star}$ & $0.01-1.14$ & 2012-17 & $-1.32^{*}$ & -2.26 to -0.37 & 2017-19 & 2.11 & $-0.74-5.05$ \\
\hline Guyana & 0.08 & $-0.21-0.36$ & 2000-06 & $-1.31^{*}$ & -1.86 to -0.76 & 2006-12 & 0.18 & $-0.52-0.88$ & 2012-19 & $1.2^{\star}$ & $0.81-1.58$ & & & \\
\hline
\end{tabular}


TABLE 3 | Continued

\begin{tabular}{|c|c|c|c|c|c|c|c|c|c|c|c|c|c|c|}
\hline \multirow[t]{2}{*}{ Country } & \multirow[t]{2}{*}{ AAPC } & \multirow[t]{2}{*}{ Range } & \multicolumn{3}{|c|}{ Trend1 } & \multicolumn{3}{|c|}{ Trend2 } & \multicolumn{3}{|c|}{ Trend3 } & \multicolumn{3}{|c|}{ Trend4 } \\
\hline & & & Period & EAPC & Range & Period & EAPC & Range & Period & EAPC & Range & Period & EAPC & Range \\
\hline Hungary & $0.43^{*}$ & $0.15-0.7$ & 2000-05 & $0.86^{\star}$ & $0.15-1.57$ & $2005-12$ & $-0.61^{*}$ & -1.12 to -0.1 & 2012-19 & $1.16^{\star}$ & $0.77-1.55$ & & & \\
\hline Iceland & $-0.63^{*}$ & -1.08 to -0.17 & 2000-07 & $1.08^{*}$ & $0.69-1.47$ & $2007-12$ & $-1.34^{*}$ & -2.18 to -0.5 & $2012-15$ & $-4.28^{\star}$ & -6.8 to -1.68 & 2015-19 & 0.1 & $-0.71-0.91$ \\
\hline Ireland & $0.38^{\star}$ & $0.1-0.65$ & 2000-04 & $3.75^{\star}$ & $3.02-4.49$ & 2004-09 & 0.33 & $-0.31-0.97$ & 2009-13 & $-2.95^{\star}$ & -3.88 to -2 & 2013-19 & $0.46^{\star}$ & $0.15-0.76$ \\
\hline Israel & -0.22 & $-0.6-0.17$ & 2000-08 & $1.82^{*}$ & $1.3-2.34$ & 2008-14 & $-3.38^{\star}$ & -4.27 to -2.47 & 2014-19 & 0.41 & $-0.46-1.29$ & & & \\
\hline Italy & -0.11 & $-0.3-0.08$ & 2000-03 & $3.22^{*}$ & 2.48-3.95 & 2003-07 & -0.04 & $-0.71-0.64$ & $2007-13$ & $-1.89^{*}$ & -2.19 to -1.6 & 2013-19 & 0.01 & $-0.22-0.24$ \\
\hline Jamaica & 0.55 & $-1.05-2.18$ & 2000-06 & 1.06 & $-0.77-2.92$ & 2006-09 & 8.21 & $-1.53-18.91$ & 2009-14 & $-4.68^{\star}$ & -7.47 to -1.8 & 2014-19 & 0.88 & $-1.14-2.95$ \\
\hline Japan & $1.46^{\star}$ & $1.3-1.62$ & 2000-05 & $5.95^{\star}$ & 5.59-6.32 & 2005-09 & $1.91^{\star}$ & $1.24-2.58$ & 2009-19 & $-0.89^{*}$ & -0.98 to -0.79 & & & \\
\hline Kazakhstan & $2.88^{\star}$ & $2.68-3.08$ & $2000-11$ & $3.29^{*}$ & $3.21-3.36$ & 2011-14 & $2.08^{*}$ & $1.11-3.05$ & 2014-17 & $4.44^{*}$ & $3.53-5.35$ & 2017-19 & -0.42 & $-1.21-0.37$ \\
\hline Kuwait & $2.34^{*}$ & $1.19-3.5$ & 2000-03 & 0.1 & $-3.74-4.09$ & 2003-08 & $5.49^{\star}$ & $3.21-7.82$ & 2008-11 & -3.6 & $-9.3-2.45$ & 2011-19 & $3.55^{\star}$ & $3-4.11$ \\
\hline Kyrgyzstan & 0.35 & $-0.12-0.82$ & 2000-04 & $-3.06^{\star}$ & -3.94 to -2.16 & $2004-12$ & $0.9^{*}$ & $0.49-1.31$ & 2012-15 & 2.69 & $-0.16-5.63$ & 2015-19 & $0.97^{\star}$ & $0.17-1.78$ \\
\hline Latvia & $2.99^{\star}$ & $2.54-3.44$ & $2000-07$ & $6.92^{\star}$ & $6.52-7.33$ & $2007-11$ & 0.38 & $-0.84-1.63$ & 2011-14 & $2.94^{\star}$ & $0.49-5.44$ & 2014-19 & -0.22 & $-0.74-0.3$ \\
\hline Lithuania & $2.12^{\star}$ & $1.47-2.78$ & 2000-04 & $6.41^{*}$ & $4.86-7.98$ & $2004-07$ & $10.16^{*}$ & $5.87-14.61$ & $2007-19$ & $-1.16^{*}$ & -1.38 to -0.94 & & & \\
\hline Luxembourg & $-0.52^{*}$ & -0.79 to -0.24 & 2000-04 & $1.76^{\star}$ & $1.06-2.46$ & 2004-08 & -0.56 & $-1.58-0.47$ & $2008-16$ & $-1.99^{*}$ & -2.25 to -1.73 & 2016-19 & 0.5 & $-0.43-1.44$ \\
\hline Malta & $0.25^{*}$ & $0.04-0.46$ & 2000-09 & $1.25^{\star}$ & $1.01-1.48$ & 2009-15 & $-1.48^{\star}$ & -1.95 to -1 & 2015-19 & 0.62 & $-0.03-1.28$ & & & \\
\hline Mauritius & $0.23^{\star}$ & $-0.34-0.79$ & 2000-02 & 2.71 & $-1.2-6.77$ & 2002-06 & -1.8 & $-3.61-0.03$ & $2006-17$ & 0.22 & $-0.04-0.47$ & 2017-19 & 1.95 & $-0.81-4.78$ \\
\hline Mexico & $0.99^{\star}$ & $0.78-1.21$ & 2000-05 & $1.05^{\star}$ & $0.44-1.66$ & $2005-16$ & $0.44^{\star}$ & $0.27-0.62$ & 2016-19 & $2.95^{\star}$ & $1.98-3.93$ & & & \\
\hline $\begin{array}{l}\text { The } \\
\text { Netherlands }\end{array}$ & $0.7^{\star}$ & $0.45-0.94$ & 2000-03 & $4.6^{*}$ & $3.2-6.02$ & 2003-14 & $-0.25^{\star}$ & -0.44 to -0.07 & 2014-19 & $0.51^{*}$ & $0.03-0.99$ & & & \\
\hline $\begin{array}{l}\text { New } \\
\text { Zealand }\end{array}$ & $-0.43^{*}$ & -0.81 to -0.05 & 2000-02 & 0.09 & $-2.07-2.31$ & 2002-05 & $-2.94^{\star}$ & -5.03 to -0.8 & 2005-13 & $-1.08^{\star}$ & -1.36 to -0.8 & 2013-19 & $1.55^{\star}$ & $1.23-1.88$ \\
\hline Nicaragua & $3.03^{*}$ & $2.61-3.45$ & $2000-12$ & $3.77^{\star}$ & $3.56-3.97$ & $2012-15$ & -0.04 & $-2.59-2.58$ & 2015-19 & $3.15^{\star}$ & 2.39-3.92 & & & \\
\hline $\begin{array}{l}\text { North } \\
\text { Macedonia }\end{array}$ & $2.18^{\star}$ & $1.97-2.4$ & $2000-05$ & $3.02^{*}$ & $2.61-3.44$ & 2005-09 & $4.07^{\star}$ & $3.25-4.9$ & 2009-16 & $1.59^{*}$ & $1.35-1.83$ & 2016-19 & -0.27 & $-0.9-0.36$ \\
\hline Norway & 0.12 & $-0.09-0.33$ & 2000-09 & $2.05^{\star}$ & $1.68-2.42$ & 2009-19 & $-1.58^{\star}$ & -1.85 to -1.32 & & & & & & \\
\hline Panama & $0.53^{\star}$ & $0.28-0.79$ & $2000-13$ & $-0.41^{\star}$ & -0.67 to -0.16 & 2013-19 & $2.62^{*}$ & 1.93-3.31 & & & & & & \\
\hline Paraguay & $1.82^{*}$ & $1.56-2.08$ & 2000-04 & $2.53^{\star}$ & $1.51-3.56$ & $2004-13$ & $0.62^{*}$ & $0.32-0.92$ & 2013-19 & $3.17^{*}$ & $2.78-3.56$ & & & \\
\hline Peru & $1.84^{*}$ & $1.51-2.18$ & 2000-04 & $2.15^{\star}$ & $1.56-2.74$ & 2004-07 & 0.49 & $-1.16-2.17$ & $2007-10$ & $4.17^{*}$ & $2.59-5.78$ & 2010-19 & $1.39^{\star}$ & $1.27-1.51$ \\
\hline Philippines & $0.58^{*}$ & $0.34-0.81$ & 2000-07 & $-0.75^{\star}$ & -1.14 to -0.36 & $2007-13$ & $2.51^{*}$ & $1.92-3.1$ & 2013-19 & 0.23 & $-0.15-0.6$ & & & \\
\hline Poland & $1.41^{*}$ & $1.32-1.49$ & 2000-09 & $2.52^{\star}$ & 2.43-2.62 & 2009-15 & $0.93^{*}$ & $0.72-1.13$ & 2015-19 & $-0.35^{*}$ & -0.61 to -0.1 & & & \\
\hline Portugal & $0.68^{*}$ & $0.51-0.85$ & 2000-04 & $1.75^{\star}$ & $1.14-2.37$ & $2004-13$ & $-0.25^{\star}$ & -0.45 to -0.05 & 2013-19 & $1.37^{\star}$ & $1.08-1.67$ & & & \\
\hline $\begin{array}{l}\text { Korea, } \\
\text { Republic of }\end{array}$ & $2.63^{\star}$ & $2.46-2.8$ & 2000-04 & $7.24^{*}$ & $6.51-7.96$ & $2004-10$ & $4.48^{*}$ & $4.11-4.85$ & 2010-19 & $-0.54^{*}$ & -0.66 to -0.43 & & & \\
\hline $\begin{array}{l}\text { Republic of } \\
\text { Moldova }\end{array}$ & $4.77^{\star}$ & $4.35-5.2$ & $2000-16$ & $5.97^{*}$ & $5.7-6.24$ & 2016-19 & -1.37 & $-3.77-1.09$ & & & & & & \\
\hline Romania & $2.81^{*}$ & $2.61-3.01$ & $2000-12$ & $3.44^{*}$ & $3.21-3.67$ & 2012-19 & $1.74^{*}$ & $1.31-2.17$ & & & & & & \\
\hline $\begin{array}{l}\text { Russian } \\
\text { Federation }\end{array}$ & $3.57^{\star}$ & $3.28-3.86$ & $2000-15$ & $4.67^{\star}$ & $4.45-4.89$ & 2015-19 & -0.46 & $-1.66-0.76$ & & & & & & \\
\hline
\end{tabular}


TABLE 3 | Continued

\begin{tabular}{|c|c|c|c|c|c|c|c|c|c|c|c|c|c|c|}
\hline \multirow[t]{2}{*}{ Country } & \multirow[t]{2}{*}{ AAPC } & \multirow[t]{2}{*}{ Range } & \multicolumn{3}{|c|}{ Trend1 } & \multicolumn{3}{|c|}{ Trend2 } & \multicolumn{3}{|c|}{ Trend3 } & \multicolumn{3}{|c|}{ Trend4 } \\
\hline & & & Period & EAPC & Range & Period & EAPC & Range & Period & EAPC & Range & Period & EAPC & Range \\
\hline Saint Lucia & $0.42^{\star}$ & $0.24-0.6$ & $2000-11$ & $-0.5^{\star}$ & -0.74 to -0.26 & 2011-19 & $1.71^{\star}$ & $1.38-2.03$ & & & & & & \\
\hline Serbia & $2.63^{\star}$ & $2.45-2.82$ & 2000-08 & $5.06^{\star}$ & 4.79-5.32 & $2008-15$ & $1.69^{\star}$ & $1.36-2.02$ & 2015-19 & -0.45 & $-1.02-0.12$ & & & \\
\hline Singapore & $1.4^{\star}$ & $1.17-1.62$ & 2000-09 & $3.07^{\star}$ & $2.64-3.51$ & 2009-19 & -0.09 & $-0.34-0.16$ & & & & & & \\
\hline Slovakia & $1.97^{\star}$ & $1.78-2.17$ & 2000-04 & $1.27^{\star}$ & $0.69-1.84$ & 2004-09 & $4.93^{*}$ & $4.4-5.47$ & 2009-15 & $2.11^{*}$ & $1.79-2.42$ & 2015-19 & $-1.12^{*}$ & $\begin{array}{c}-1.51 \text { to } \\
-0.73\end{array}$ \\
\hline Slovenia & $2.05^{\star}$ & $1.82-2.28$ & 2000-09 & $4.13^{\star}$ & $3.71-4.56$ & 2009-19 & 0.21 & $-0.07-0.49$ & & & & & & \\
\hline South Africa & $0.69^{\star}$ & $0.53-0.86$ & 2000-05 & $-0.39^{*}$ & -0.72 to -0.06 & 2005-10 & $2.56^{\star}$ & $2.12-3$ & 2010-16 & $1.59^{*}$ & $1.32-1.86$ & 2016-19 & $-2.32^{*}$ & $\begin{array}{c}-2.85 \text { to } \\
-1.78\end{array}$ \\
\hline Spain & -0.06 & $-0.22-0.11$ & 2000-03 & $2.86^{*}$ & $2.2-3.53$ & 2003-09 & $-0.35^{*}$ & -0.62 to -0.07 & 2009-13 & $-1.95^{\star}$ & -2.54 to -1.36 & 2013-19 & 0.07 & $-0.13-0.27$ \\
\hline Sri Lanka & $2.48^{\star}$ & $2.2-2.76$ & 2000-04 & $2.44^{\star}$ & $1.32-3.56$ & 2004-12 & $3.56^{\star}$ & $3.16-3.96$ & 2012-19 & $1.28^{*}$ & $0.97-1.59$ & & & \\
\hline Suriname & $1.24^{\star}$ & $0.69-1.8$ & 2000-02 & 3.96 & $-0.56-8.68$ & 2002-09 & -0.02 & $-0.7-0.67$ & 2009-14 & $2.25^{*}$ & $1.1-3.41$ & 2014-19 & $0.95^{\star}$ & $0.24-1.66$ \\
\hline Sweden & $-0.48^{*}$ & -0.68 to -0.28 & 2000-04 & $2.09^{*}$ & $1.42-2.77$ & $2004-16$ & $-1.45^{\star}$ & -1.58 to -1.32 & 2016-19 & 0.05 & $-0.93-1.03$ & & & \\
\hline Switzerland & $-0.88^{*}$ & -1.02 to -0.73 & 2000-04 & $1.18^{\star}$ & $0.79-1.57$ & 2004-09 & $-1.53^{\star}$ & -1.89 to -1.16 & 2009-15 & $-2.33^{*}$ & -2.58 to -2.08 & 2015-19 & 0.1 & $-0.26-0.45$ \\
\hline $\begin{array}{l}\text { Syrian Arab } \\
\text { Republic }\end{array}$ & $1.23^{\star}$ & 0.68-1.79 & 2000-04 & $-1.85^{\star}$ & -3.14 to -0.53 & 2004-12 & $3.3^{*}$ & $2.81-3.8$ & 2012-15 & $-0.39^{\star}$ & $-3.45-2.76$ & 2015-19 & $1.49^{\star}$ & $0.55-2.44$ \\
\hline Tajikistan & $1.37^{\star}$ & $1.05-1.69$ & $2000-16$ & $1.75^{\star}$ & $1.58-1.93$ & 2016-19 & -0.67 & $-2.61-1.31$ & & & & & & \\
\hline Thailand & $1.14^{\star}$ & $0.95-1.33$ & $2000-13$ & $0.73^{\star}$ & $0.53-0.93$ & 2013-19 & $2.04^{\star}$ & $1.55-2.53$ & & & & & & \\
\hline $\begin{array}{l}\text { Trinidad and } \\
\text { Tobago }\end{array}$ & $0.31^{\star}$ & $0.1-0.52$ & 2000-08 & $0.45^{\star}$ & $0.19-0.72$ & 2008-13 & $-0.71^{\star}$ & -1.38 to -0.03 & 2013-19 & $0.96^{*}$ & $0.64-1.29$ & & & \\
\hline Turkey & $2.36^{\star}$ & $1.97-2.74$ & 2000-04 & $9.74^{\star}$ & $8.45-11.05$ & $2004-11$ & $0.77^{*}$ & $0.25-1.29$ & 2011-16 & -0.73 & $-1.58-0.13$ & 2016-19 & $1.81^{*}$ & $0.54-3.09$ \\
\hline Turkmenistan & $1.64^{\star}$ & $0.99-2.29$ & 2000-02 & -1.29 & $-5.44-3.04$ & 2002-06 & $4.1^{\star}$ & $2.05-6.2$ & $2006-10$ & -0.15 & $-1.96-1.69$ & 2010-19 & $2.01^{\star}$ & $1.73-2.3$ \\
\hline Ukraine & $1.56^{\star}$ & $1.18-1.94$ & 2000-06 & -0.53 & $-1.62-0.57$ & 2006-19 & $2.53^{*}$ & $2.21-2.86$ & & & & & & \\
\hline United Kingdom & $n 0.93^{*}$ & $0.67-1.19$ & 2000-02 & $3.16^{\star}$ & $1.56-4.79$ & 2002-09 & $1.04^{\star}$ & $0.79-1.28$ & 2009-12 & -0.02 & $-1.38-1.37$ & 2012-19 & $0.6^{*}$ & $0.43-0.78$ \\
\hline $\begin{array}{l}\text { United States } \\
\text { of America }\end{array}$ & $-0.69^{*}$ & -0.92 to -0.46 & 2000-02 & -1 & $-2.56-0.6$ & 2002-06 & $-1.92^{*}$ & -2.69 to -1.14 & 2006-15 & $-0.59^{\star}$ & -0.75 to -0.43 & 2015-19 & $0.49^{*}$ & $0.06-0.91$ \\
\hline Uruguay & 0.29 & $-0.05-0.62$ & 2000-04 & $2.99^{*}$ & 2.09-3.89 & $2004-10$ & 0.14 & $-0.45-0.73$ & 2010-15 & $-2.34^{*}$ & -3.15 to -1.52 & 2015-19 & $1.17^{\star}$ & $0.35-2.01$ \\
\hline Uzbekistan & $1.42^{\star}$ & $0.99-1.85$ & 2000-02 & $3.57^{\star}$ & $0.95-6.26$ & $2002-12$ & $1.4^{*}$ & $1.17-1.63$ & 2012-15 & 0.02 & $-2.24-2.33$ & 2015-19 & $1.46^{\star}$ & $0.77-2.15$ \\
\hline $\begin{array}{l}\text { Venezuela, } \\
\text { Bolivarian } \\
\text { Republic of }\end{array}$ & $1.45^{\star}$ & $0.4-2.5$ & 2000-08 & $4.63^{\star}$ & $3.06-6.24$ & $2008-15$ & $-2.98^{\star}$ & -4.8 to -1.12 & 2015-19 & 3.1 & $-0.05-6.35$ & & & \\
\hline
\end{tabular}


TABLE 4 | Trend analysis of age-standardized mortality for prostate cancer from 2000 to 2019.

\begin{tabular}{|c|c|c|c|c|c|c|c|c|c|c|c|c|c|c|}
\hline \multirow[t]{2}{*}{ Country } & \multirow[t]{2}{*}{ AAPC } & \multirow[t]{2}{*}{ Range } & \multicolumn{3}{|c|}{ Trend1 } & \multicolumn{3}{|c|}{ Trend2 } & \multicolumn{3}{|c|}{ Trend3 } & \multicolumn{3}{|c|}{ Trend4 } \\
\hline & & & Period & EAPC & Range & Period & EAPC & Range & Period & EAPC & Range & Period & EAPC & Range \\
\hline Albania & 0.05 & $-0.47-0.57$ & 2000-04 & 0.81 & $-0.67-2.32$ & 2004-08 & $-2.72^{\star}$ & -4.86 to -0.54 & 2008-19 & $0.8^{\star}$ & $0.54-1.06$ & & & \\
\hline Argentina & $-0.9^{*}$ & -1.01 to -0.78 & $2000-03$ & 0.09 & $-0.34-0.52$ & 2003-07 & $-0.9^{\star}$ & -1.31 to -0.48 & $2007-14$ & $-1.8^{\star}$ & -1.94 to -1.67 & 2014-19 & $-0.2^{\star}$ & -0.37 to -0.02 \\
\hline Armenia & $1^{*}$ & $0.76-1.25$ & $2000-16$ & $1.32^{\star}$ & $1.18-1.46$ & 2016-19 & -0.65 & $-2.14-0.87$ & & & & & & \\
\hline Australia & $-1.1^{*}$ & -1.2 to -0.99 & 2000-03 & 0.38 & $-0.06-0.82$ & 2003-08 & $-1.35^{\star}$ & -1.61 to -1.09 & 2008-14 & $-2.99^{*}$ & -3.17 to -2.82 & 2014-19 & $0.59^{\star}$ & $0.42-0.76$ \\
\hline Austria & $-1.73^{*}$ & -1.87 to -1.6 & 2000-04 & $-3.09^{\star}$ & -3.55 to -2.61 & 2004-14 & $-1.77^{\star}$ & -1.91 to -1.64 & 2014-19 & $-0.55^{\star}$ & -0.88 to -0.23 & & & \\
\hline Azerbaijan & $0.43^{\star}$ & $0.29-0.58$ & 2000-03 & $2.83^{*}$ & $2.12-3.55$ & 2003-17 & $0.27^{\star}$ & $0.21-0.33$ & 2017-19 & $-1.94^{\star}$ & -2.97 to -0.89 & & & \\
\hline Bahamas & -0.16 & $-0.9-0.58$ & 2000-02 & 3.3 & $-1.19-8$ & 2002-05 & -2.58 & $-6.6-1.61$ & 2005-19 & -0.12 & $-0.29-0.05$ & & & \\
\hline Bahrain & -0.26 & $-1-0.49$ & 2000-04 & $6.02^{*}$ & $2.91-9.22$ & $2004-14$ & $-3.04^{\star}$ & -3.75 to -2.32 & 2014-19 & 0.51 & $-0.94-1.98$ & & & \\
\hline Barbados & -0.17 & $-0.51-0.16$ & 2000-04 & $1.38^{*}$ & $0.53-2.24$ & 2004-12 & $-2.61^{\star}$ & -2.94 to -2.27 & 2012-17 & 0.17 & $-0.61-0.95$ & 2017-19 & $5.91^{\star}$ & $3.6-8.27$ \\
\hline Belarus & 0.26 & $-0.03-0.54$ & 2000-10 & $0.9^{*}$ & $0.48-1.32$ & 2010-19 & -0.45 & $-0.91-0.01$ & & & & & & \\
\hline Belgium & $-1.75^{\star}$ & -1.97 to -1.53 & $2000-07$ & $-1.61^{*}$ & -1.78 to -1.44 & $2007-13$ & $-3.65^{\star}$ & -3.93 to -3.36 & 2013-16 & -1.17 & $-2.47-0.15$ & 2016-19 & $1.24^{\star}$ & $0.6-1.88$ \\
\hline Belize & $-0.91^{*}$ & -1.35 to -0.48 & 2000-03 & $-2.27^{\star}$ & -3.5 to -1.04 & 2003-06 & -0.5 & $-2.9-1.95$ & 2006-10 & $-3.28^{*}$ & -4.41 to -2.13 & 2010-19 & $0.48^{*}$ & $0.29-0.66$ \\
\hline Brazil & $-0.98^{\star}$ & -1.14 to -0.83 & 2000-04 & 0.25 & $-0.18-0.68$ & 2004-09 & $-1.1^{*}$ & -1.49 to -0.71 & 2009-14 & $-2^{*}$ & -2.37 to -1.63 & 2014-19 & $-0.82^{\star}$ & -1.06 to -0.57 \\
\hline $\begin{array}{l}\text { Brunei } \\
\text { Darussalam }\end{array}$ & $1.89^{\star}$ & $1.47-2.31$ & $2000-13$ & $3.43^{*}$ & $3-3.85$ & 2013-19 & $-1.35^{\star}$ & -2.43 to -0.26 & & & & & & \\
\hline Bulgaria & $2.17^{\star}$ & $1.94-2.41$ & 2000-08 & $4.68^{\star}$ & $4.38-4.99$ & $2008-13$ & $1.87^{\star}$ & $1.13-2.61$ & 2013-19 & $-0.84^{*}$ & -1.21 to -0.46 & & & \\
\hline Canada & $-2.19^{\star}$ & -2.65 to -1.74 & 2000-04 & $-2^{*}$ & -2.86 to -1.14 & 2004-12 & $-4.63^{\star}$ & -4.99 to -4.27 & 2012-15 & -1.06 & $-3.81-1.77$ & 2015-19 & $1.79^{\star}$ & $0.95-2.63$ \\
\hline Chile & $-0.52^{\star}$ & -0.78 to -0.27 & $2000-12$ & $-0.33^{\star}$ & -0.47 to -0.19 & $2012-16$ & $-1.55^{\star}$ & -2.58 to -0.51 & 2016-19 & 0.1 & $-0.89-1.1$ & & & \\
\hline China & $-0.59^{*}$ & -0.69 to -0.5 & 2000-08 & $-0.82^{\star}$ & -1.01 to -0.62 & 2008-19 & $-0.43^{\star}$ & -0.53 to -0.33 & & & & & & \\
\hline Colombia & $-1.31^{*}$ & $-2.65-0.05$ & 2000-02 & 3.77 & $-4.23-12.43$ & 2002-05 & -5.74 & $-12.68-1.75$ & 2005-15 & $-1.87^{\star}$ & -2.54 to -1.21 & 2015-19 & 1.05 & $-1.03-3.19$ \\
\hline Costa Rica & -0.19 & $-0.38-0.01$ & 2000-19 & -0.19 & $-0.38-0.01$ & & & & & & & & & \\
\hline Croatia & $0.4^{*}$ & $0.14-0.66$ & 2000-05 & $2.38^{*}$ & $1.65-3.12$ & 2005-15 & -0.04 & $-0.3-0.21$ & 2015-19 & $-0.94^{\star}$ & -1.75 to -0.12 & & & \\
\hline Cuba & $0.54^{\star}$ & $0.39-0.69$ & 2000-09 & $0.8^{\star}$ & $0.53-1.07$ & 2009-19 & $0.3^{*}$ & $0.11-0.5$ & & & & & & \\
\hline Czechia & $-0.97^{\star}$ & -1.16 to -0.78 & 2000-04 & 0.33 & $-0.2-0.87$ & $2004-10$ & $-1.17^{\star}$ & -1.52 to -0.82 & 2010-15 & $-2.3^{\star}$ & -2.77 to -1.83 & 2015-19 & -0.28 & $-0.75-0.19$ \\
\hline Denmark & $-0.78^{\star}$ & -0.94 to -0.62 & 2000-05 & $1.3^{*}$ & $1.03-1.58$ & 2005-09 & $-0.77^{\star}$ & -1.34 to -0.19 & 2009-14 & $-3.12^{*}$ & -3.47 to -2.77 & 2014-19 & $-0.48^{\star}$ & -0.73 to -0.24 \\
\hline $\begin{array}{l}\text { Dominican } \\
\text { Republic }\end{array}$ & -0.5 & $-1.04-0.05$ & 2000-05 & $2.16^{\star}$ & $1.36-2.96$ & 2005-08 & $-5.12^{\star}$ & -8.22 to -1.92 & 2008-15 & $0.91^{\star}$ & $0.37-1.45$ & 2015-19 & $-2.65^{\star}$ & -3.57 to -1.72 \\
\hline Ecuador & 0.14 & $-0.02-0.31$ & 2000-06 & $1.88^{\star}$ & $1.53-2.22$ & $2006-12$ & -0.23 & $-0.62-0.15$ & 2012-19 & $-1^{*}$ & -1.2 to -0.79 & & & \\
\hline El Salvador & -0.04 & $-0.86-0.78$ & 2000-02 & -2.21 & $-7.76-3.68$ & 2002-06 & $2.81^{*}$ & $0.01-5.69$ & 2006-13 & $-2.65^{\star}$ & -3.52 to -1.76 & 2013-19 & $1.91^{*}$ & $1.06-2.78$ \\
\hline Estonia & $0.48^{\star}$ & $0.24-0.72$ & 2000-06 & $2.55^{\star}$ & $2.04-3.07$ & $2006-15$ & 0.11 & $-0.17-0.4$ & 2015-19 & $-1.74^{\star}$ & -2.51 to -0.97 & & & \\
\hline Finland & $-1.44^{\star}$ & -1.6 to -1.28 & 2000-02 & -1.05 & $-2.27-0.18$ & 2002-08 & $-3.07^{*}$ & -3.33 to -2.8 & 2008-14 & $-1.3^{\star}$ & -1.56 to -1.04 & 2014-19 & 0.22 & $-0.02-0.47$ \\
\hline France & $-2.19^{\star}$ & -2.39 to -2 & 2000-03 & $-2.02^{\star}$ & -2.58 to -1.46 & $2003-11$ & $-3.75^{\star}$ & -3.9 to -3.6 & 2011-14 & $-3.02^{*}$ & -4.18 to -1.84 & 2014-19 & $0.75^{*}$ & $0.5-1.01$ \\
\hline Georgia & $3.63^{*}$ & $3.19-4.07$ & 2000-05 & $10.27^{\star}$ & $8.97-11.6$ & 2005-12 & $3.02^{*}$ & $2.24-3.82$ & 2012-19 & -0.3 & $-0.87-0.28$ & & & \\
\hline Germany & $-1.41^{*}$ & -1.53 to -1.28 & 2000-08 & $-1.97^{\star}$ & -2.04 to -1.89 & $2008-11$ & $-2.31^{*}$ & -2.99 to -1.62 & $2011-15$ & $-1.08^{\star}$ & -1.43 to -0.73 & 2015-19 & 0.08 & $-0.14-0.3$ \\
\hline Greece & $-1.3^{\star}$ & -1.49 to -1.11 & 2000-03 & -1.03 & -1.74 to -0.31 & $2003-11$ & $-3.16^{*}$ & -3.35 to -2.97 & 2011-16 & -0.16 & $-0.64-0.31$ & 2016-19 & $1.58^{*}$ & $0.85-2.32$ \\
\hline Guatemala & $-0.42^{*}$ & -0.7 to -0.13 & 2000-05 & $1.32^{\star}$ & $0.86-1.79$ & 2005-14 & $-1.1^{\star}$ & -1.28 to -0.91 & 2014-17 & $-2.02^{*}$ & -3.56 to -0.46 & 2017-19 & 0.79 & $-0.7-2.31$ \\
\hline Guyana & -0.33 & $-0.65-0$ & 2000-04 & $-1.38^{*}$ & -2.05 to -0.71 & $2004-11$ & -0.14 & $-0.48-0.21$ & 2011-14 & 1.13 & $-0.82-3.11$ & 2014-19 & $-0.61^{*}$ & -1.02 to -0.19 \\
\hline
\end{tabular}




\begin{tabular}{|c|c|c|c|c|c|c|c|c|c|c|c|c|c|c|}
\hline \multirow[t]{2}{*}{ Country } & \multirow[t]{2}{*}{ AAPC } & \multirow[t]{2}{*}{ Range } & \multicolumn{3}{|c|}{ Trend1 } & \multicolumn{3}{|c|}{ Trend2 } & \multicolumn{3}{|c|}{ Trend3 } & \multicolumn{3}{|c|}{ Trend4 } \\
\hline & & & Period & EAPC & Range & Period & EAPC & Range & Period & EAPC & Range & Period & EAPC & Range \\
\hline Hungary & $-1.08^{\star}$ & -1.23 to -0.93 & 2000-13 & $-1.64^{*}$ & -1.77 to -1.51 & 2013-19 & 0.13 & $-0.3-0.57$ & & & & & & \\
\hline Iceland & $-1.53^{\star}$ & -1.94 to -1.11 & 2000-11 & $-0.81^{*}$ & -1 to -0.62 & $2011-14$ & $-5.3^{\star}$ & -7.83 to -2.7 & 2014-19 & $-0.81^{\star}$ & -1.39 to -0.21 & & & \\
\hline Ireland & $-1.85^{\star}$ & -2.05 to -1.64 & 2000-04 & $-1.69^{*}$ & -2.08 to -1.3 & 2004-14 & $-2.73^{\star}$ & -2.84 to -2.62 & $2014-17$ & -0.64 & $-1.8-0.55$ & 2017-19 & 0.49 & $-0.63-1.63$ \\
\hline Israel & $-1.99^{*}$ & -2.51 to -1.46 & 2000-09 & $-1.93^{\star}$ & -2.2 to -1.66 & $2009-13$ & $-4.47^{\star}$ & -5.89 to -3.03 & 2013-16 & -1.32 & $-4.19-1.63$ & 2016-19 & 0.54 & $-0.84-1.95$ \\
\hline Italy & $-1.54^{*}$ & -1.63 to -1.45 & 2000-03 & $-1.61^{*}$ & -2.08 to -1.14 & 2003-14 & $-2.25^{\star}$ & -2.32 to -2.18 & 2014-19 & 0.07 & $-0.14-0.28$ & & & \\
\hline Jamaica & 0.23 & $-1.07-1.55$ & $2000-06$ & -0.49 & $-1.85-0.89$ & 2006-09 & $8.46^{\star}$ & $0.79-16.72$ & 2009-13 & $-5.07^{\star}$ & -8.5 to -1.51 & 2013-19 & 0.64 & $-0.56-1.85$ \\
\hline Japan & $-0.68^{\star}$ & -0.81 to -0.54 & $2000-05$ & $-0.38^{*}$ & -0.57 to -0.19 & 2005-08 & $-1.47^{*}$ & -2.24 to -0.68 & 2008-17 & $-0.79^{*}$ & -0.87 to -0.71 & 2017-19 & 0.28 & $-0.45-1.01$ \\
\hline Kazakhstan & $0.65^{\star}$ & $0.22-1.09$ & $2000-11$ & $1.35^{\star}$ & $1.19-1.5$ & 2011-14 & -0.73 & $-2.72-1.3$ & 2014-17 & 1.24 & $-0.75-3.27$ & 2017-19 & $-1.91^{*}$ & -3.73 to -0.06 \\
\hline Kuwait & 0.53 & $-0.13-1.19$ & 2000-08 & $2.12^{*}$ & $1.57-2.67$ & $2008-11$ & $-5.23^{\star}$ & -9.19 to -1.09 & 2011-19 & $1.17^{\star}$ & $0.76-1.58$ & & & \\
\hline Kyrgyzstan & -0.95 & $-1.97-0.08$ & 2000-03 & $-4.44^{*}$ & -7.26 to -1.54 & $2003-13$ & $-1^{*}$ & -1.59 to -0.42 & 2013-16 & 3.29 & $-2.74-9.69$ & 2016-19 & -1.35 & $-4.12-1.51$ \\
\hline Latvia & $0.97^{\star}$ & $0.7-1.23$ & 2000-06 & $5.14^{\star}$ & $4.56-5.72$ & $2006-14$ & -0.28 & $-0.67-0.1$ & 2014-19 & $-1.89^{\star}$ & -2.53 to -1.26 & & & \\
\hline Lithuania & $0.52^{\star}$ & $0.14-0.91$ & 2000-07 & $5.43^{\star}$ & $4.91-5.94$ & 2007-11 & $-3.03^{*}$ & -4.62 to -1.42 & 2011-19 & $-1.83^{\star}$ & -2.2 to -1.46 & & & \\
\hline Luxembourg & $-2.21^{*}$ & -2.54 to -1.88 & 2000-02 & $-4.37^{\star}$ & -6.55 to -2.14 & 2002-06 & $-1.92^{\star}$ & -3.05 to -0.77 & 2006-15 & $-3.09^{\star}$ & -3.33 to -2.85 & 2015-19 & 0.61 & $-0.07-1.29$ \\
\hline Malta & $-1.76^{\star}$ & -2.17 to -1.35 & 2000-13 & $-1.62^{*}$ & -1.77 to -1.48 & 2013-16 & $-4.42^{*}$ & -6.86 to -1.92 & 2016-19 & 0.35 & $-0.89-1.6$ & & & \\
\hline Mauritius & $-0.68^{\star}$ & -0.83 to -0.53 & 2000-19 & $-0.68^{\star}$ & -0.83 to -0.53 & & & & & & & & & \\
\hline Mexico & $-0.34^{*}$ & -0.52 to -0.16 & $2000-16$ & $-0.51^{*}$ & -0.61 to -0.41 & 2016-19 & 0.59 & $-0.53-1.71$ & & & & & & \\
\hline $\begin{array}{l}\text { The } \\
\text { Netherlands }\end{array}$ & $-1.06^{\star}$ & -1.34 to -0.77 & $2000-03$ & 0.16 & $-0.7-1.03$ & 2003-06 & $-3.6^{*}$ & -5.24 to -1.93 & 2006-13 & $-1.54^{*}$ & -1.82 to -1.26 & 2013-19 & 0.19 & $-0.07-0.45$ \\
\hline $\begin{array}{l}\text { New } \\
\text { Zealand }\end{array}$ & $-1.6^{\star}$ & -1.92 to -1.28 & $2000-05$ & $-3.38^{\star}$ & -3.93 to -2.83 & 2005-12 & $-2.08^{\star}$ & -2.5 to -1.66 & 2012-17 & -0.44 & $-1.18-0.32$ & 2017-19 & 1.74 & $-0.48-4.01$ \\
\hline Nicaragua & 0.26 & $-0.02-0.54$ & 2000-05 & $1.77^{\star}$ & $1.22-2.32$ & 2005-12 & $-0.27^{\star}$ & $-0.63-0.09$ & 2012-16 & $-1.78^{\star}$ & -2.76 to -0.79 & 2016-19 & $1.79^{\star}$ & $0.84-2.75$ \\
\hline $\begin{array}{l}\text { North } \\
\text { Macedonia }\end{array}$ & $0.72^{\star}$ & $0.53-0.9$ & $2000-07$ & $1.4^{*}$ & $1.1-1.71$ & 2007-16 & $0.81^{\star}$ & $0.6-1.03$ & 2016-19 & $-1.16^{\star}$ & -2.04 to -0.27 & & & \\
\hline Norway & $-1.3^{\star}$ & -1.44 to -1.16 & $2000-07$ & $-1.06^{\star}$ & -1.23 to -0.88 & 2007-17 & $-1.7^{\star}$ & -1.82 to -1.59 & 2017-19 & -0.16 & $-1.37-1.06$ & & & \\
\hline Panama & $-0.81^{*}$ & -1.1 to -0.52 & 2000-03 & 0.9 & $-0.71-2.54$ & 2003-11 & $-1.48^{\star}$ & -1.86 to -1.09 & 2011-19 & $-0.77^{\star}$ & -1.05 to -0.49 & & & \\
\hline Paraguay & 0.1 & $-0.19-0.39$ & 2000-04 & $1.59^{\star}$ & $0.81-2.37$ & 2004-10 & $-0.51^{*}$ & -1 to -0.02 & 2010-14 & $-1.21^{*}$ & -2.23 to -0.18 & 2014-19 & $0.69^{\star}$ & $0.25-1.12$ \\
\hline Peru & $-0.37^{\star}$ & -0.59 to -0.16 & $2000-07$ & $-0.9^{\star}$ & -1.09 to -0.71 & 2007-10 & $2.83^{*}$ & $1.51-4.18$ & 2010-15 & $-1.62^{\star}$ & -1.99 to -1.24 & 2015-19 & -0.26 & $-0.61-0.1$ \\
\hline Philippines & 0.11 & $-0.02-0.25$ & 2000-04 & $-1.47^{\star}$ & -1.85 to -1.09 & 2004-09 & $0.71^{*}$ & $0.35-1.07$ & $2009-15$ & $1.1^{*}$ & $0.87-1.33$ & 2015-19 & $-0.5^{\star}$ & -0.79 to -0.21 \\
\hline Poland & $-0.35^{\star}$ & -0.52 to -0.17 & 2000-06 & -0.07 & $-0.39-0.24$ & 2006-11 & $-1.06^{\star}$ & -1.61 to -0.5 & 2011-19 & -0.11 & $-0.28-0.07$ & & & \\
\hline Portugal & $-1.72^{\star}$ & -1.83 to -1.62 & 2000-02 & $-3.24^{*}$ & -3.99 to -2.49 & $2002-07$ & $-2.53^{\star}$ & -2.77 to -2.29 & $2007-14$ & $-2.11^{*}$ & -2.24 to -1.98 & 2014-19 & $0.27^{*}$ & $0.1-0.44$ \\
\hline $\begin{array}{l}\text { Korea, } \\
\text { Republic of }\end{array}$ & $-0.48^{\star}$ & -0.67 to -0.28 & $2000-08$ & $0.63^{*}$ & $0.47-0.78$ & 2008-11 & -0.31 & $-1.44-0.85$ & 2011-16 & $-2.07^{\star}$ & -2.39 to -1.74 & 2016-19 & $-0.9^{*}$ & -1.37 to -0.43 \\
\hline $\begin{array}{l}\text { Republic of } \\
\text { Moldova }\end{array}$ & $2.6^{*}$ & $2.2-3$ & 2000-15 & $3.82^{\star}$ & $3.53-4.11$ & 2015-19 & $-1.86^{\star}$ & -3.54 to -0.15 & & & & & & \\
\hline Romania & $0.54^{\star}$ & $0.27-0.8$ & 2000-07 & 0.19 & $-0.23-0.61$ & 2007-15 & $1.2^{*}$ & $0.8-1.59$ & 2015-19 & -0.17 & $-1.02-0.69$ & & & \\
\hline $\begin{array}{l}\text { Russian } \\
\text { Federation }\end{array}$ & $0.87^{\star}$ & $0.68-1.05$ & 2000-15 & $1.54^{\star}$ & $1.41-1.67$ & 2015-19 & $-1.63^{\star}$ & -2.45 to -0.8 & & & & & & \\
\hline Saint Lucia & -0.17 & $-0.62-0.27$ & $2000-02$ & 0.84 & $-3.17-5.02$ & $2002-11$ & $-1.93^{\star}$ & -2.34 to -1.53 & 2011-19 & $1.59^{*}$ & $1.23-1.95$ & & & \\
\hline
\end{tabular}


TABLE 4 | Continued

\begin{tabular}{|c|c|c|c|c|c|c|c|c|c|c|c|c|c|c|}
\hline \multirow[t]{2}{*}{ Country } & \multirow[t]{2}{*}{ AAPC } & \multirow[t]{2}{*}{ Range } & \multicolumn{3}{|c|}{ Trend1 } & \multicolumn{3}{|c|}{ Trend2 } & \multicolumn{3}{|c|}{ Trend3 } & \multicolumn{3}{|c|}{ Trend4 } \\
\hline & & & Period & EAPC & Range & Period & EAPC & Range & Period & EAPC & Range & Period & EAPC & Range \\
\hline Serbia & $0.91^{*}$ & $0.45-1.36$ & $2000-07$ & $3.75^{\star}$ & $3.36-4.15$ & $2007-11$ & -1.12 & $-2.38-0.15$ & $2011-14$ & 0.97 & $-1.53-3.55$ & 2014-19 & $-1.4^{\star}$ & -1.94 to -0.85 \\
\hline Singapore & $-1.14^{\star}$ & -1.36 to -0.91 & 2000-03 & $-2.71^{*}$ & -3.77 to -1.63 & 2003-08 & -0.4 & $-1.05-0.26$ & 2008-19 & $-1.04^{\star}$ & -1.15 to -0.93 & & & \\
\hline Slovakia & -0.08 & $-0.34-0.18$ & 2000-04 & -1.64 & -2.19 to -1.08 & 2004-12 & 1.73 & $1.51-1.96$ & 2012-15 & -0.2 & $-1.69-1.32$ & 2015-19 & -1.99 & -2.44 to -1.53 \\
\hline Slovenia & -0.58 & -0.86 to -0.3 & $2000-10$ & -0.22 & -0.43 to -0.01 & 2010-14 & -2.3 & -3.5 to -1.08 & 2014-19 & 0.09 & $-0.43-0.62$ & & & \\
\hline South Africa & $-0.32^{*}$ & -0.48 to -0.16 & 2000-05 & $-0.82^{\star}$ & -1.12 to -0.51 & 2005-10 & $1.19^{*}$ & $0.78-1.61$ & 2010-16 & 0.2 & $-0.07-0.47$ & 2016-19 & $-2.99^{\star}$ & -3.54 to -2.44 \\
\hline Spain & $-1.66^{\star}$ & -1.83 to -1.48 & $2000-07$ & $-2.87^{\star}$ & -3 to -2.73 & 2007-12 & $-2.02^{\star}$ & -2.35 to -1.7 & 2012-15 & $-1.35^{\star}$ & -2.37 to -0.31 & 2015-19 & $0.72^{\star}$ & $0.4-1.04$ \\
\hline Sri Lanka & 0.05 & $-0.09-0.19$ & $2000-12$ & $0.75^{\star}$ & $0.58-0.91$ & 2012-19 & $-1.12^{*}$ & -1.43 to -0.82 & & & & & & \\
\hline Suriname & $0.36^{*}$ & $0.02-0.7$ & 2000-02 & $4.01^{*}$ & $1.76-6.3$ & 2002-11 & $-0.82^{*}$ & -1.04 to -0.61 & 2011-14 & $2.23^{\star}$ & $0.41-4.1$ & 2014-19 & -0.06 & $-0.43-0.31$ \\
\hline Sweden & $-1.53^{\star}$ & -1.64 to -1.43 & 2000-04 & $-0.86^{\star}$ & -1.24 to -0.48 & 2004-14 & $-2.37^{\star}$ & -2.48 to -2.26 & 2014-19 & $-0.39^{\star}$ & -0.65 to -0.12 & & & \\
\hline Switzerland & $-1.69^{*}$ & -1.83 to -1.55 & $2000-13$ & $-2.32^{*}$ & -2.37 to -2.28 & 2013-16 & -0.59 & $-1.46-0.29$ & 2016-19 & -0.01 & $-0.43-0.41$ & & & \\
\hline $\begin{array}{l}\text { Syrian Arab } \\
\text { Republic }\end{array}$ & -0.13 & $-0.48-0.22$ & 2000-03 & $-3.24^{\star}$ & -4.21 to -2.26 & 2003-06 & -0.98 & $-2.92-0.99$ & 2006-10 & $2.19^{*}$ & $1.26-3.13$ & 2010-19 & $0.19^{*}$ & $0.05-0.34$ \\
\hline Tajikistan & $0.75^{\star}$ & $0.54-0.97$ & 2000-09 & $0.79^{\star}$ & $0.61-0.98$ & $2009-17$ & $1.6^{\star}$ & $1.35-1.85$ & $2017-19$ & $-2.75^{\star}$ & -4.5 to -0.97 & & & \\
\hline Thailand & $-0.94^{*}$ & -1.16 to -0.73 & 2000-02 & $-4.09^{\star}$ & -6.04 to -2.1 & $2002-13$ & $-1.22^{*}$ & -1.36 to -1.08 & 2013-19 & $0.64^{\star}$ & $0.38-0.9$ & & & \\
\hline $\begin{array}{l}\text { Trinidad and } \\
\text { Tobago }\end{array}$ & $-0.8^{\star}$ & -1.1 to -0.5 & 2000-08 & $-0.81^{*}$ & -1.12 to -0.49 & 2008-12 & $-2.17^{\star}$ & -3.5 to -0.82 & 2012-19 & 0 & $-0.34-0.34$ & & & \\
\hline Turkey & -0.72 & $-1.77-0.34$ & 2000-02 & $13.51^{*}$ & $7.43-19.94$ & 2002-05 & -0.51 & $-5.14-4.33$ & 2005-08 & $-6.01^{*}$ & -10.42 to -1.37 & 2008-19 & $-1.71^{\star}$ & -2.02 to -1.41 \\
\hline Turkmenistan & 0.29 & $-0.34-0.92$ & 2000-02 & -0.54 & $-4.05-3.11$ & 2002-06 & $2.47^{\star}$ & $0.77-4.21$ & 2006-09 & -2.97 & $-5.98-0.12$ & 2009-19 & $0.58^{\star}$ & $0.36-0.8$ \\
\hline Ukraine & 0.23 & $-0.13-0.59$ & 2000-09 & $-1.71^{\star}$ & -2.31 to -1.12 & 2009-19 & $2.01^{*}$ & $1.5-2.52$ & & & & & & \\
\hline United Kingdom & $n-0.73^{*}$ & -0.9 to -0.56 & 2000-02 & -0.59 & $-1.86-0.69$ & 2002-08 & $-1.78^{*}$ & -2.06 to -1.5 & 2008-14 & $-0.53^{\star}$ & -0.8 to -0.25 & 2014-19 & 0.24 & $-0.02-0.5$ \\
\hline $\begin{array}{l}\text { United States } \\
\text { of America }\end{array}$ & $-1.22^{*}$ & -1.38 to -1.06 & 2000-04 & $-2.71^{*}$ & -3.01 to -2.4 & 2004-10 & $-1.99^{*}$ & -2.21 to -1.77 & $2010-13$ & $-1.05^{\star}$ & -2 to -0.1 & 2013-19 & $0.48^{\star}$ & $0.33-0.63$ \\
\hline Uruguay & $-0.8^{\star}$ & -1.01 to -0.59 & 2000-04 & $1.21^{*}$ & $0.67-1.76$ & 2004-09 & $-1.28^{\star}$ & -1.8 to -0.75 & 2009-16 & $-2.16^{\star}$ & -2.44 to -1.88 & 2016-19 & 0.56 & $-0.29-1.41$ \\
\hline Uzbekistan & $0.52^{*}$ & $0.21-0.83$ & 2000-03 & $3.44^{\star}$ & $1.42-5.49$ & 2003-19 & -0.02 & $-0.16-0.13$ & & & & & & \\
\hline $\begin{array}{l}\text { Venezuela, } \\
\text { Bolivarian } \\
\text { Republic of }\end{array}$ & 0.17 & $-0.6-0.96$ & 2000-08 & $2.23^{*}$ & $1.13-3.34$ & 2008-15 & $-3.78^{\star}$ & -5.17 to -2.38 & 2015-19 & $3.23^{*}$ & $0.77-5.74$ & & & \\
\hline
\end{tabular}

${ }^{*} p$-value <0.05. AAPC, Average Annual Percentage Change; EAPC, Estimated Annual Percentage Change. 


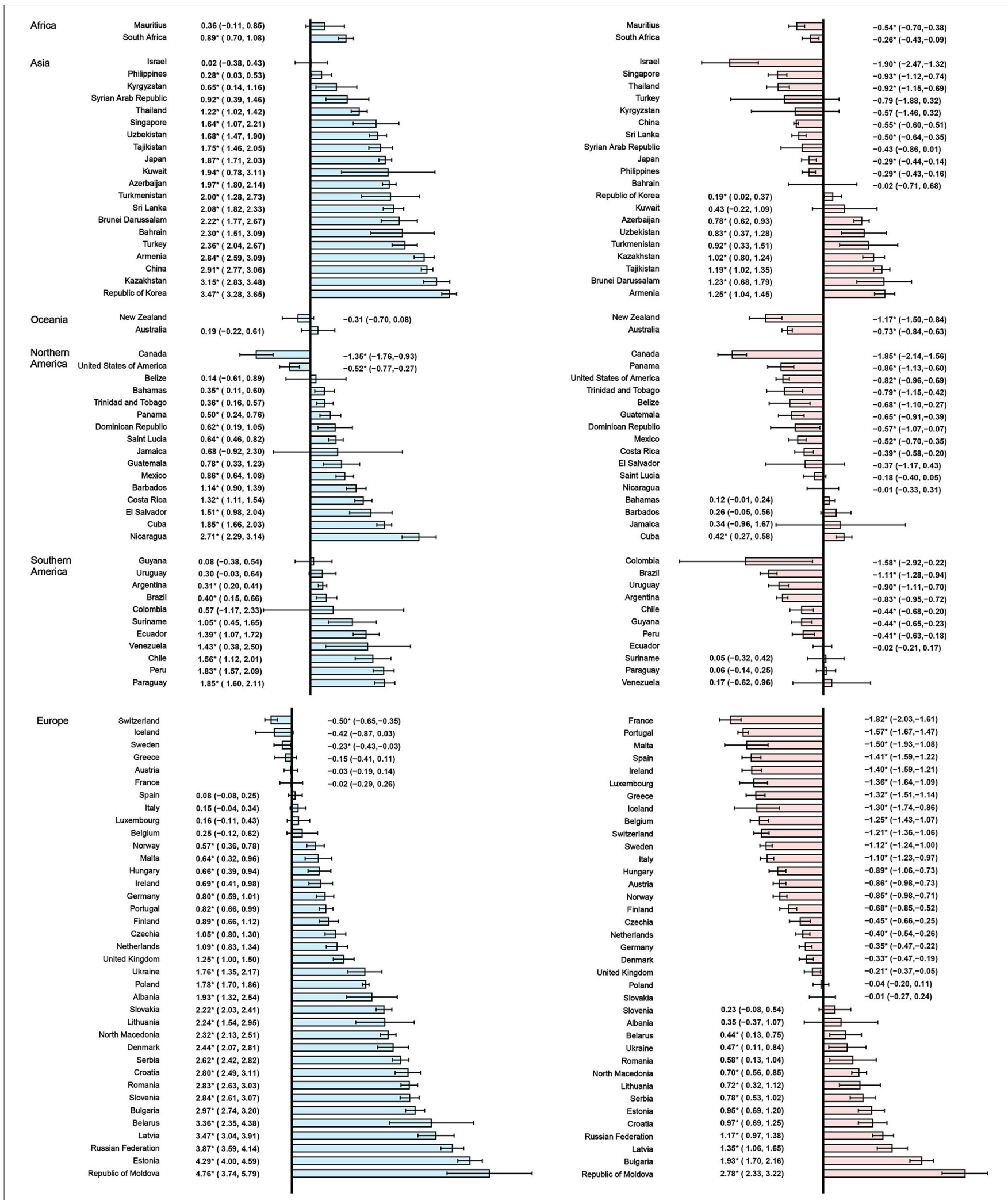

FIGURE 3 | The AAPC of the ASIR (blue bars) and ASMR (red bars) of prostate cancer. ${ }^{*} P<0.05$. AAPC, Average annual percent change; ASIR, age-standardized incidence rate; ASMR, age-standardized mortality rate. 


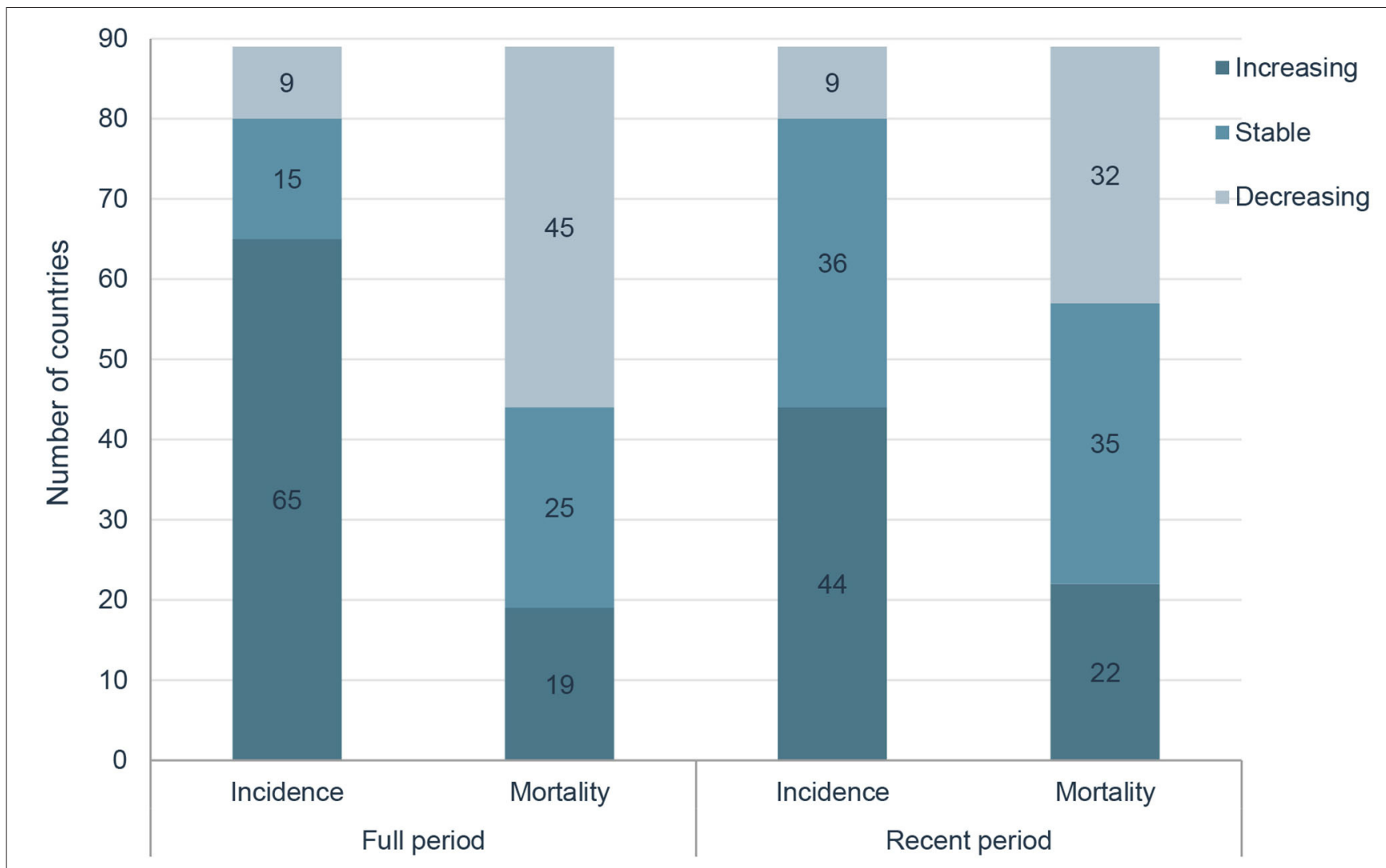

FIGURE 4 | Comparisons of changing trends in most recent period with that in full period.

may result in bias when inferring the effect of PSA screening on incidence and mortality of prostate cancer.

\section{CONCLUSIONS}

Our study provides the up-to-date status of prostate cancer incidence and mortality worldwide, and demonstrates a positive association between prostate cancer incidence and HDI, and a negative association between prostate cancer mortality and HDI. Moreover, the magnitude of increasing incidence and decreasing mortality of prostate cancer is attenuated in the recent period. Further study is needed to analyze the absolute effects of risk factors, PSA screening and advanced treatment.

\section{DATA AVAILABILITY STATEMENT}

The original contributions presented in the study are included in the article/supplementary material, further inquiries can be directed to the corresponding authors.

\section{REFERENCES}

1. Sung H, Ferlay J, Siegel RL, Laversanne M, Soerjomataram I, Jemal A, et al. Global Cancer Statistics 2020: GLOBOCAN Estimates of Incidence and

\section{AUTHOR CONTRIBUTIONS}

$\mathrm{LD}, \mathrm{ZW}$, and LW: conception and design. LW, BL, MH, and YW: acquisition, analysis, or interpretation of data. $\mathrm{LW}, \mathrm{BL}$, and $\mathrm{MH}$ : drafting of the manuscript. YW, ZW, and LD: critical revision of the manuscript for important intellectual content. BL: statistical analysis. LD: administrative, technical, or material support. LD and ZW: supervision. All authors contributed to the article and approved the submitted version.

\section{FUNDING}

This work was supported by Health Science and Technology Project of Zhejiang Province (2021KY586) and National Natural Science Foundation of China (12071032). The funders had no role in the study design and conduct; data collection, management, analysis, and interpretation; manuscript preparation, review, or approval; and the decision to submit the manuscript for publication.
Mortality Worldwide for 36 Cancers in 185 Countries. CA Cancer J Clin. (2021) 71:209-49. doi: 10.3322/caac.21660

2. Culp MB, Soerjomataram I, Efstathiou JA, Bray F, Jemal A. Recent global patterns in prostate cancer incidence and mortality 
rates. Eur Urol. (2020) 77:38-52. doi: 10.1016/j.eururo.201 9.08.005

3. Center MM, Jemal A, Lortet-Tieulent J, Ward E, Ferlay J, Brawley O, et al. International variation in prostate cancer incidence and mortality rates. Eur Urol. (2012) 61:1079-92. doi: 10.1016/j.eururo.2012.02.054

4. Allott EH, Masko EM, Freedland SJ. Obesity and prostate cancer: weighing the evidence. Eur Urol. (2013) 63:800-9. doi: 10.1016/j.eururo.2012.11.013

5. Reiter-Brennan C, Dzaye O, Al-Mallah MH, Dardari Z, Brawner CA, Lamerato LE, et al. Fitness and prostate cancer screening, incidence, and mortality: Results from the Henry Ford Exercise Testing (FIT) Project. Cancer. (2021) 127:1864-70. doi: 10.1002/cncr.33426

6. Cai H, Xu Z, Xu T, Yu B, Zou Q. Diabetes mellitus is associated with elevated risk of mortality amongst patients with prostate cancer: a metaanalysis of 11 cohort studies. Diabetes Metab Res Rev. (2015) 31:33643. doi: $10.1002 / \mathrm{dmrr} .2582$

7. Peisch SF, Van Blarigan EL, Chan JM, Stampfer MJ, Kenfield SA. Prostate cancer progression and mortality: a review of diet and lifestyle factors. World J Urol. (2017) 35:867-74. doi: 10.1007/s00345-016-1914-3

8. Klein EA, Thompson IM Jr, Tangen CM, Crowley JJ, Lucia MS, Goodman PJ, et al. Vitamin $\mathrm{E}$ and the risk of prostate cancer: the Selenium and Vitamin E Cancer Prevention Trial (SELECT). JAMA. (2011) 306:154956. doi: 10.1001/jama.2011.1437

9. United Nations Development Programme. Human Development Report 2020: The next frontier Human development and the Anthropocene. Available online at: http://hdr.undp.org/sites/default/files/hdr2020.pdf (accessed August 15, 2021).

10. Negoita S, Feuer EJ, Mariotto A, Cronin KA, Petkov VI, Hussey SK, et al. Annual Report to the Nation on the Status of Cancer, part II: Recent changes in prostate cancer trends and disease characteristics. Cancer. (2018) 124:280114. doi: $10.1002 / \mathrm{cncr} .31549$

11. LeBlanc AG, Demers A, Shaw A. Recent trends in prostate cancer in Canada. Health Rep 17. (2019) 30:12-7. doi: 10.25318/82-003-x201900400002-eng

12. Collin SM, Martin RM, Metcalfe C, Gunnell D, Albertsen PC, Neal D, et al. Prostate-cancer mortality in the USA and UK in 1975-2004: an ecological study. Lancet Oncol. (2008) 9:445-52. doi: 10.1016/S1470-2045(08)70104-9

13. Pakzad R, Mohammadian-Hafshejani A, Ghoncheh M, Pakzad I, Salehiniya $H$. The incidence and mortality of prostate cancer and its relationship with development in Asia. Prostate Int. (2015) 3:135-40. doi: 10.1016/j.prnil.2015.09.001

14. Shoag JE, Nyame YA, Gulati R, Etzioni R, Hu JC. Reconsidering the Tradeoffs of Prostate Cancer Screening. N Engl J Med Jun 18. (2020) 382:24658. doi: 10.1056/NEJMsb2000250

15. Tsodikov A, Gulati R, Heijnsdijk EAM, Pinsky PF, Moss SM, Qiu S, et al. Reconciling the Effects of Screening on Prostate Cancer Mortality in the ERSPC and PLCO Trials. Ann Intern Med. (2017) 167:44955. doi: 10.7326/M16-2586

16. Loeb S, Bjurlin MA, Nicholson J, Tammela TL, Penson DF, Carter HB, et al. Overdiagnosis and overtreatment of prostate cancer. Eur Urol. (2014) 65:1046-55. doi: 10.1016/j.eururo.2013.12.062

17. Sanghera S, Coast J, Martin RM, Donovan JL, Mohiuddin S. Cost-effectiveness of prostate cancer screening: a systematic review of decision-analytical models. BMC Cancer. (2018) 18:84. doi: 10.1186/s12885-017-3974-1

18. Wolf AM, Wender RC, Etzioni RB, Thompson IM, D’Amico AV, Volk RJ, et al. American Cancer Society guideline for the early detection of prostate cancer: update 2010. CA Cancer J Clin. (2010) 60:70-98. doi: 10.3322/caac.20066

19. Basch E, Oliver TK, Vickers A, Thompson I, Kantoff P, Parnes H, et al. Screening for prostate cancer with prostate-specific antigen testing: American Society of Clinical Oncology Provisional Clinical Opinion. J Clin Oncol 20. (2012) 30:3020-5. doi: 10.1200/JCO.2012.43.3441

20. Qaseem A, Barry MJ, Denberg TD, Owens DK, Shekelle P. Screening for prostate cancer: a guidance statement from the Clinical Guidelines Committee of the American College of Physicians. Ann Intern Med 21. (2013) 158:7619. doi: 10.7326/0003-4819-158-10-201305210-00633

21. Bell N, Connor Gorber S, Shane A, Joffres M, Singh H, Dickinson $\mathrm{J}$, et al. Recommendations on screening for prostate cancer with the prostate-specific antigen test. CMAJ. (2014) 186:1225-34. doi: 10.1503/cmaj.1 40703
22. Prostate Cancer Foundation of Australia, Cancer Council Australia. PSA Testing Guidelines Expert Advisory Panel. PSA Testing and Early Management of Test-Detected Prostate Cancer: Clinical Practice Guidelines. 2016-01-20. Available online at: https://www.prostate.org.au/media/612113/PSA-TestingGuidelines.pdf (accessed August 20, 2021).

23. Kakehi Y, Sugimoto M, Taoka R. Evidenced-based clinical practice guideline for prostate cancer (summary: Japanese Urological Association, 2016 edition). Int J Urol. (2017) 24:648-66. doi: 10.1111/iju.13380

24. Rendon RA, Mason RJ, Marzouk K, Finelli A, Saad F, So A, et al. Canadian Urological Association recommendations on prostate cancer screening and early diagnosis. Can Urol Assoc J. (2017) 11:298-309. doi: 10.5489/cuaj.4888

25. Screening for prostate cancer: U.S. Preventive Services Task Force recommendation statement. Ann Intern Med. 2008;149:18591. doi: 10.7326/0003-4819-149-3-200808050-00008

26. Drazer MW, Huo D, Eggener SE. National Prostate Cancer Screening Rates After the 2012 US Preventive Services Task Force Recommendation Discouraging Prostate-Specific Antigen-Based Screening. J Clin Oncol. (2015) 33:2416-23. doi: 10.1200/JCO.2015.61.6532

27. Zargar H, van den Bergh R, Moon D, Lawrentschuk N, Costello A, Murphy D. The impact of the United States Preventive Services Task Force (USPTSTF) recommendations against prostate-specific antigen (PSA) testing on PSA testing in Australia. BJU Int. (2017) 119:110-5. doi: 10.1111/bju.13602

28. Jemal A, Culp MB, Ma J, Islami F, Fedewa SA. Prostate Cancer Incidence 5 Years After US Preventive Services Task Force Recommendations Against Screening. J Natl Cancer Inst. (2021) 113:64-71. doi: 10.1093/jnci/djaa068

29. Kensler KH, Pernar CH, Mahal BA, Nguyen PL, Trinh QD, Kibel AS, et al. Racial and Ethnic Variation in PSA Testing and Prostate Cancer Incidence Following the 2012 USPSTF Recommendation. J Natl Cancer Inst. (2021) 113:719-26. doi: 10.1093/jnci/djaa171

30. Nyame YA, Gulati R, Tsodikov A, Gore JL, Etzioni R. Prostate-Specific Antigen Screening and Recent Increases in Advanced Prostate Cancer. JNCI Cancer Spectr. (2021) 5:pkaa098. doi: 10.1093/jncics/pkaa098

31. Grossman DC, Curry SJ, Owens DK, Bibbins-Domingo K, Caughey $\mathrm{AB}$, Davidson KW, et al. Screening for Prostate Cancer: US Preventive Services Task Force Recommendation Statement. JAMA. (2018) 319:190113. doi: $10.1001 /$ jama.2018.3710

32. Mottet N, van den Bergh RCN, Briers E, Van den Broeck T, Cumberbatch MG, De Santis M, et al. EAU-EANM-ESTRO-ESUR-SIOG Guidelines on Prostate Cancer-2020 Update. Part 1: screening, diagnosis, and local treatment with curative intent. Eur Urol. (2021) 79:243-62. doi: 10.1016/j.eururo.2020.09.042

33. National Comprehensive Cancer Network. NCCN Guidelines for Prostate Cancer Early Detection Version 2.2021. 2021-07-14. Available online at: $\quad$ https://www.nccn.org/login?ReturnURL=https://www.nccn.org/ professionals/physician_gls/pdf/prostate_detection.pdf (accessed August 21, 2021).

34. Prostate Cancer Working Group of Genitourinary Cancer Committee in Chinese Anti-Cancer Association. China consensus of prostate cancer screening (2021). China Oncol. (2021) 31:435-40. doi: 10.19401/j.cnki.1007-3639.2021.05.010

35. Ferlay J, Ervik M, Lam F, Colombet M, Mery L, Piñeros M, Znaor A, Soerjomataram I, F B. Global Cancer Observatory: Cancer Today. 2020-12. Available online at: https://gco.iarc.fr/today/ (accessed August 15, 2021).

36. Institute for Health Metrics and Evaluation. GHDx: GBD Results Tool. Available online at: http://ghdx.healthdata.org/gbd-results-tool (accessed August 15, 2021).

37. Global burden of 369 diseases and injuries in 204 countries and territories, 1990-2019: a systematic analysis for the Global Burden of Disease Study 2019. Lancet. (2020) 396:1204-22. doi: 10.1016/S0140-6736(20)3 0925-9

38. Lu B, Li N, Luo CY, Cai J, Lu M, Zhang YH, et al. Colorectal cancer incidence and mortality: the current status, temporal trends and their attributable risk factors in 60 countries in 2000-2019. Chin Med J (Engl). (2021) 134:194151. doi: $10.1097 / \mathrm{CM} 9.0000000000001619$

39. Luo CY, Li N, Lu B, Cai J, Lu M, Zhang YH, et al. Global and regional trends in incidence and mortality of female breast cancer and associated factors at national level in 2000 to 2019. Chin Med J (Engl). (2021) 135:4251. doi: $10.1097 / \mathrm{CM} 9.0000000000001814$ 
40. Kim HJ, Fay MP, Feuer EJ, Midthune DN. Permutation tests for joinpoint regression with applications to cancer rates. Stat Med. (2000) 19:33551. doi: 10.1002/(sici)1097-0258(20000215)19:3<335::aid-sim336>3.0.co;2-z

41. Division of Cancer Control \& Population Sciences NCI. Joinpoint Trend Analysis Software. 2021-03-25. Available online at: https://surveillance.cancer. gov/joinpoint/ (accessed August 15, 2021).

42. Sharma R. The burden of prostate cancer is associated with human development index: evidence from 87 countries, 1990-2016. EPMA J. (2019) 10:137-52. doi: 10.1007/s13167-019-00169-y

43. Zhai Z, Zheng Y, Li N, Deng Y, Zhou L, Tian T, et al. Incidence and disease burden of prostate cancer from 1990 to 2017: Results from the Global Burden of Disease Study 2017. Cancer. (2020) 126:1969-78. doi: 10.1002/cncr.32733

44. Taioli E, Flores-Obando RE, Agalliu I, Blanchet P, Bunker $\mathrm{CH}$, Ferrell RE, et al. Multi-institutional prostate cancer study of genetic susceptibility in populations of African descent. Carcinogenesis. (2011) 32:1361-5. doi: 10.1093/carcin/bgr119

45. Zeigler-Johnson CM, Spangler E, Jalloh M, Gueye SM, Rennert H, Rebbeck TR. Genetic susceptibility to prostate cancer in men of African descent: implications for global disparities in incidence and outcomes. Can J Urol. (2008) 15:3872-82.

46. Mahal BA, Gerke T, Awasthi S, Soule HR, Simons JW, Miyahira A, et al. Prostate cancer racial disparities: a systematic review by the prostate cancer foundation panel. Eur Urol Oncol. (2021). doi: 10.1016/j.euo.2021.07.006. [Epub ahead of print].

47. Siegel DA, O’Neil ME, Richards TB, Dowling NF, Weir HK. Prostate Cancer Incidence and Survival, by Stage and Race/Ethnicity United States, 2001-2017. MMWR Morb Mortal Wkly Rep. (2020) 69:1473-80. doi: 10.15585/mmwr.mm6941a1

48. Andriole GL, Crawford ED, Grubb RL 3rd, Buys SS, Chia D, Church TR, et al. Prostate cancer screening in the randomized Prostate, Lung, Colorectal, and Ovarian Cancer Screening Trial: mortality results after 13 years of follow-up. J Natl Cancer Inst. (2012) 104:125-32. doi: 10.1093/jnci/djr500

49. Schröder FH, Hugosson J, Roobol MJ, Tammela TL, Zappa M, Nelen V, et al. Screening and prostate cancer mortality: results of the European Randomised Study of Screening for Prostate Cancer (ERSPC) at 13 years of follow-up. Lancet. (2014) 384:2027-35. doi: 10.1016/S0140-6736(14)60525-0

50. Hugosson J, Godtman RA, Carlsson SV, Aus G, Grenabo Bergdahl A, Lodding P, et al. Eighteen-year follow-up of the Göteborg Randomized Populationbased Prostate Cancer Screening Trial: effect of sociodemographic variables on participation, prostate cancer incidence and mortality. Scand J Urol. (2018) 52:27-37. doi: 10.1080/21681805.2017.1411392

51. Pernar CH, Ebot EM, Wilson KM, Mucci LA. The epidemiology of prostate cancer. Cold Spring Harb Perspect Med. (2018) 8:a030361. doi: 10.1101/cshperspect.a030361

52. Zhu Y, Mo M, Wei Y, Wu J, Pan J, Freedland SJ, et al. Epidemiology and genomics of prostate cancer in Asian men. Nat Rev Urol. (2021) 18:282301. doi: 10.1038/s41585-021-00442-8

53. Zhang K, Bangma CH, Roobol MJ. Prostate cancer screening in Europe and Asia. Asian J Urol. (2017) 4:86-95. doi: 10.1016/j.ajur.2016.08.010

54. Kimura T, Egawa S. Epidemiology of prostate cancer in Asian countries. Int $J$ Urol. (2018) 25:524-31. doi: 10.1111/iju.13593

55. Welton M, Robb SW, Shen Y, Guillebeau P, Vena J. Prostate cancer incidence and agriculture practices in Georgia, 2000-2010. Int J Occup Environ Health. (2015) 21:251-7. doi: 10.1179/2049396714Y.0000000106
56. Wang Y, Zhao L, Gao L, Pan A, Xue H. Health policy and public health implications of obesity in China. Lancet Diabetes Endocrinol. (2021) 9:44661. doi: 10.1016/S2213-8587(21)00118-2

57. Allemani C, Matsuda T, Di Carlo V, Harewood R, Matz M, Nikšić M, et al. Global surveillance of trends in cancer survival 2000-14 (CONCORD-3): analysis of individual records for 37513025 patients diagnosed with one of 18 cancers from 322 population-based registries in 71 countries. Lancet. (2018) 391:1023-75. doi: 10.1016/S0140-6736(17)33326-3

58. Zeng H, Chen W, Zheng R, Zhang S, Ji JS, Zou X, et al. Changing cancer survival in China during 2003-15: a pooled analysis of 17 population-based cancer registries. Lancet Global Health. (2018) 6:e55567. doi: 10.1016/S2214-109X(18)30127-X

59. Moyer VA. Screening for prostate cancer: U. S Preventive Services Task Force recommendation statement. Ann Intern Med. (2012) 157:120 34. doi: 10.7326/0003-4819-157-2-201207170-00459

60. Goldenberg MG, Skeldon SC, Nayan M, Suppiah Y, Chow L, Fryml E, et al. Prostate-specific antigen testing for prostate cancer screening: a national survey of Canadian primary care physicians' opinions and practices. Can Urol Assoc J. (2017) 11:396-403. doi: 10.5489/cuaj.4486

61. Li J, Xu C, Lee HJ, Ren S, Zi X, Zhang Z, et al. A genomic and epigenomic atlas of prostate cancer in Asian populations. Nature. (2020) 580:939. doi: 10.1038/s41586-020-2135-x

62. Schumacher FR, Al Olama AA, Berndt SI, Benlloch S, Ahmed M, Saunders EJ, et al. Association analyses of more than 140,000 men identify 63 new prostate cancer susceptibility loci. Nat Genet. (2018) 50:92836. doi: 10.1038/s41588-018-0142-8

63. Sinha A, Huang V, Livingstone J, Wang J, Fox NS, Kurganovs N, et al. The proteogenomic landscape of curable prostate cancer. Cancer Cell. (2019) 35:414-427.e6. doi: 10.1016/j.ccell.2019.02.005

64. Wu L, Yang Y, Guo X, Shu XO, Cai Q, Shu X, et al. An integrative multi-omics analysis to identify candidate DNA methylation biomarkers related to prostate cancer risk. Nat Commun. (2020) 11:3905. doi: 10.1038/s41467-020-17673-9

65. Mattiuzzi C, Lippi G. Cancer statistics: a comparison between World Health Organization (WHO) and Global Burden of Disease (GBD). Eur J Public Health. (2020) 30:1026-7. doi: 10.1093/eurpub/ckz216

Conflict of Interest: The authors declare that the research was conducted in the absence of any commercial or financial relationships that could be construed as a potential conflict of interest.

Publisher's Note: All claims expressed in this article are solely those of the authors and do not necessarily represent those of their affiliated organizations, or those of the publisher, the editors and the reviewers. Any product that may be evaluated in this article, or claim that may be made by its manufacturer, is not guaranteed or endorsed by the publisher.

Copyright (c) 2022 Wang, Lu, He, Wang, Wang and Du. This is an open-access article distributed under the terms of the Creative Commons Attribution License (CC $B Y)$. The use, distribution or reproduction in other forums is permitted, provided the original author(s) and the copyright owner(s) are credited and that the original publication in this journal is cited, in accordance with accepted academic practice. No use, distribution or reproduction is permitted which does not comply with these terms. 